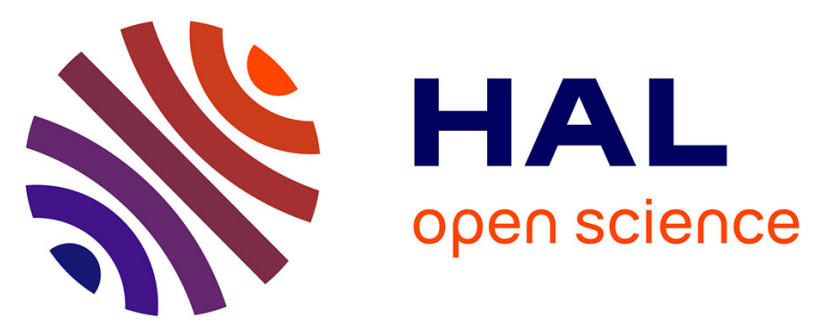

\title{
Probing permeability and microstructure: Unravelling the role of a low-permeability dome on the explosivity of Merapi (Indonesia)
}

\author{
Alexandra Roma Larisa Kushnir, Caroline Martel, Jean-Louis Bourdier, \\ Michael Heap, Thierry Reuschlé, Saskia Erdmann, Jean-Christophe \\ Komorowski, Noer Cholik
}

\section{To cite this version:}

Alexandra Roma Larisa Kushnir, Caroline Martel, Jean-Louis Bourdier, Michael Heap, Thierry Reuschlé, et al.. Probing permeability and microstructure: Unravelling the role of a low-permeability dome on the explosivity of Merapi (Indonesia). Journal of Volcanology and Geothermal Research, 2016, 316, pp.56-71. 10.1016/j.jvolgeores.2016.02.012 . insu-01280492

\section{HAL Id: insu-01280492 \\ https://hal-insu.archives-ouvertes.fr/insu-01280492}

Submitted on 29 Feb 2016

HAL is a multi-disciplinary open access archive for the deposit and dissemination of scientific research documents, whether they are published or not. The documents may come from teaching and research institutions in France or abroad, or from public or private research centers.
L'archive ouverte pluridisciplinaire HAL, est destinée au dépôt et à la diffusion de documents scientifiques de niveau recherche, publiés ou non, émanant des établissements d'enseignement et de recherche français ou étrangers, des laboratoires publics ou privés.

\section{(1) (1) $\$$}

Distributed under a Creative Commons Attribution - NonCommercial - NoDerivatives 44.0 


\section{Accepted Manuscript}

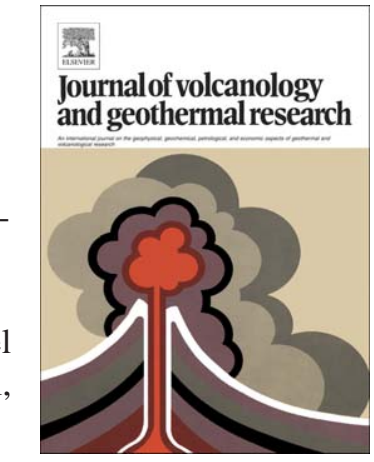

Probing permeability and microstructure: Unravelling the role of a lowpermeability dome on the explosivity of Merapi (Indonesia)

Alexandra R.L. Kushnir, Caroline Martel, Jean-Louis Bourdier, Michael J. Heap, Thierry Reuschlé, Saskia Erdmann, Jean-Christophe Komorowski, Noer Cholik

PII: $\quad$ S0377-0273(16)00056-1

DOI: doi: $10.1016 /$ j.jvolgeores.2016.02.012

Reference: $\quad$ VOLGEO 5762

To appear in: Journal of Volcanology and Geothermal Research

Received date: 28 September 2015

Accepted date: $\quad 10$ February 2016

Please cite this article as: Kushnir, Alexandra R.L., Martel, Caroline, Bourdier, JeanLouis, Heap, Michael J., Reuschlé, Thierry, Erdmann, Saskia, Komorowski, JeanChristophe, Cholik, Noer, Probing permeability and microstructure: Unravelling the role of a low-permeability dome on the explosivity of Merapi (Indonesia), Journal of Volcanology and Geothermal Research (2016), doi: 10.1016/j.jvolgeores.2016.02.012

This is a PDF file of an unedited manuscript that has been accepted for publication. As a service to our customers we are providing this early version of the manuscript. The manuscript will undergo copyediting, typesetting, and review of the resulting proof before it is published in its final form. Please note that during the production process errors may be discovered which could affect the content, and all legal disclaimers that apply to the journal pertain. 
Probing permeability and microstructure: Unravelling the role of a low-permeability dome on the explosivity of Merapi (Indonesia)

\author{
Authors: \\ Kushnir, Alexandra R.L. ${ }^{a^{*}}$ \\ Martel, Caroline ${ }^{\mathrm{a}}$ \\ Bourdier, Jean-Louis ${ }^{\mathrm{a}}$ \\ Heap, Michael J. \\ Reuschlé, Thierry ${ }^{\mathrm{b}}$ \\ Erdmann, Saskia ${ }^{\mathrm{a}}$ \\ Komorowski, Jean-Christophe ${ }^{c}$ \\ Cholik, Noer ${ }^{\mathrm{d}}$
}

a Institut des Sciences de la Terre d'Orléans, UMR 7327 - CNRS/Université d'Orléans/BRGM, 1A, Rue de la Férollerie, 45071 Orléans Cedex 2, France

${ }^{\mathrm{b}}$ Géophysique Expérimentale, Institut de Physique de Globe de Strasbourg (UMR 7516 CNRS, Université de Strasbourg/EOST), Strasbourg, France,

${ }^{c}$ Institut de Physique du Globe de Paris, Sorbonne Paris Cité, Université Paris Diderot, UMR CNRS 7154, 1, rue Jussieu, Paris 75238 Cedex 05, France

${ }^{\mathrm{d}}$ BPPTK (Balai Penyelidikan dan Pengembangan Tekonologi Kegunungapian), Jalan Cendana 15, Yogyakarta, 55166, Indonesia

Submitted to Journal of Volcanology and Geothermal Research

Keywords: permeability, specific surface area, basaltic andesite, Merapi, cristobalite, diktytaxitic textures

*Corresponding author: Email address: alexandra.kushnir@gmail.com (Alexandra R.L. Kushnir) 


\begin{abstract}
Low permeability dome rocks may contribute to conduit overpressure development in volcanic systems, indirectly abetting explosive activity. The permeability of dome-forming rocks is primarily controlled by the volume, type (vesicles and/or microcracks), and connectivity of the void space present. Here we investigate the permeability-porosity relationship of dome-forming rocks and pumice clasts from Merapi's 1888 to 2013 eruptions and assess their possible role in eruptive processes, with particular emphasis on the 2010 paroxysmal eruption. Rocks are divided into three simple field classifications common to all eruptions: Type 1 samples have low bulk density and are pumiceous in texture; Type 2 samples, ubiquitous to the 2010 eruption, are dark grey to black in hand sample and vary greatly in vesicularity; and Type 3 samples are weakly vesicular, light grey in hand sample, and are the only samples that contain cristobalite. Type 2 and Type 3 rocks are present in all eruptions and their permeability and porosity data define similar power law relationships, whereas data for Type 1 samples are clearly discontinuous from these trends. A compilation of permeability and porosity data for andesites and basaltic andesites with published values highlights two microstructural transitions that exert control on permeability, confirmed by modified Bayesian Information Criterion (BIC) analysis. Permeability is microcrack- and diktytaxitic-controlled at connected porosities, $\varphi_{c},<10.5$ vol.\%; vesicle- and microcrack-controlled at $10.5<\varphi_{c}<31$ vol. $\%$; and likely vesicle-controlled for $\varphi_{c}>31$ vol. $\%$. Type 3 basaltic andesites, the least permeable of the measured samples and therefore the most likely to have originated in the uppermost low-permeability dome, are identified as relicts of terminal domes (the last dome extruded prior to quiescence). Cristobalite commonly found in the voids of Type 3 blocks may not contribute significantly to the reduction of the permeability of these samples, mainly because it is associated with an extensive microporous, diktytaxitic texture. Indeed, the low permeability of these rocks is more likely associated with their lower fracture density. We propose that diktytaxitic textures may arise from late-stage gas filter pressing of a silica-rich melt phase, which leaves behind a microlite-supported groundmass and cristobalite in neighbouring vesicles. Due to the ubiquity of the Type 3 rocks in all Merapi eruptions, we do not invoke the emplacement of a low-permeability cap as having favoured a particularly high pressurization and subsequent high explosivity of the 2010 eruption. The debate as to the reasons for the highly explosive 2010 eruption rages on.
\end{abstract}




\section{Introduction}

Permeability and porosity are intimately yet complexly linked. Volcanologists are keenly interested in the role of permeability on the outgassing behaviour of volcanic systems. Low permeability rocks and magma can impede volcanic outgassing (e.g. Sparks (1997); Yokoo et al. (2009)), increasing conduit overpressures and, thus, raising the likelihood of explosive activity (e.g. Melnik et al. (2005); Diller et al. (2006)). In particular, a low permeability vent plug may facilitate conduit overpressure development resulting in explosive behaviour (e.g. Clarke et al. (2002); Iguchi et al. (2008); Johnson et al. (2008); Boudon et al. (2015)). Conversely, more permeable magmas (e.g. highly vesiculated magmas; Martel and Iacono-Marziano (2015); Kennedy et al. (2016)), heavily fractured lava domes (e.g. Jaupart (1998); Hicks et al. (2009)), and/or highly damaged halo zones in the edifice rocks that envelop the conduit (Rust et al., 2004; Lavallée et al., 2013; Gaunt et al., 2014; Farquharson et al., 2016) may aid outgassing, reducing the probability of explosive behaviour (e.g. Eichelberger et al. (1986); Woods and Koyaguchi (1994)).

The permeability of rocks is generally positively correlated with porosity (e.g., Bourbié and Zinszner (1985)). In volcanic rocks, both vesicles and microcracks can contribute to overall porosity, resulting in microstructurally complex porosity networks (Sparks, 1997; Heap et al., 2014b; Farquharson et al., 2015). Vesicles in volcanic rocks are the frozen relicts of gas exsolution and bubble growth, their size and number varying widely from system to system (Sparks, 1978). Microcracks can form as a result of cooling (e.g., Vinciguerra et al. (2005)) and tumbling of blocks down volcano flanks (e.g., Siebert (1984)). The mobility and fate of magmatic volatiles depends on the interconnection of these tortuous networks of vesicles and microcracks. In particular, the geometry of these microstructural elements, including the vesicle diameter and elongation, is a strong modifier of the porosity-permeability relationship (Rust and Cashman, 2004; Mueller et al., 2005; Mueller et al., 2008; Bouvet de Maisonneuve et al., 2009; Degruyter et al., 2010; Heap et al., 2014b). For instance, for any given connected porosity, permeability can vary by up to 4 orders of magnitude (Wright et al., 2006; Farquharson et al., 2015). Local porosity and permeability may also be subject to change over time. Once permeable pathways may become blocked through the precipitation of fluid-transported minerals (e.g. cristobalite, alunite, clays) into vesicles (Komorowski et al., 1997; Wright et al., 2011; Horwell et al., 2013; Ball et al., 2015). Cristobalite, in particular, is often found in volcanic dome rocks (Swanson et al., 1989; Boudon et al., 1998; Baxter et al., 1999; Blundy and Cashman, 2001; Komorowski et al., 2010; Williamson et al., 2010; Horwell et al., 2013) and in lava flows (de Hoog and van 
Bergen, 2000; de Hoog et al., 2005; Schipper et al., 2015) and its formation may significantly alter microstructure (Wright et al., 2011; Horwell et al., 2013; Boudon et al., 2015).

To assess the complex relationships between microstructure and permeability in volcanic rocks, we present a systematic study of the microstructure, porosity, permeability, and specific surface area of basaltic andesitic pyroclasts erupted at Merapi (Indonesia) in the last 30 years, including those from the paroxysmal 2010 eruption. Although the explosive 2010 eruption excavated a large portion of the historical domes (Surono et al., 2012; Jousset et al., 2013b; Komorowski et al., 2013), we source rock samples from the extensive archive of dome and pyroclastic density current (PDCs) deposits dating back to 1888 at the Institut des Sciences de la Terre d'Orléans (ISTO, France). By considering the dominant relationships between microstructure and permeability, we discuss their implications for the development or dissipation of magmatic overpressures and, thus, eruption explosivity.

\section{Merapi's eruptive dynamics and the paroxysmal 2010 eruption}

Merapi, in Central Java, Indonesia, is a basaltic andesitic stratovolcano that has been largely effusive and dome-building for much of the last hundred years (Surono et al., 2012; Jousset et al., 2013b) and is commonly used as a type example for generating concentrated PDCs by dome destabilisation (i.e. Merapi-type nuées ardentes; Abdurachman et al. (2000) and references therein). Since 1872, eruptions have been characterized by viscous lava dome growth and collapse and occur roughly every 4 to 6 years (Surono et al., 2012; Pallister et al., 2013). Between 1890 and 1996, lava dome extrusion rates ranged between $0.01 \mathrm{~m}^{3} \mathrm{~s}^{-1}$ and $0.7 \mathrm{~m}^{3} \mathrm{~s}^{-1}$ (Siswowidjoyo et al., 1995; Hammer et al., 2000). In 2006, the eruptive behaviour changed. The 2006 eruption had a notably high average extrusion rate of $2.4 \mathrm{~m}^{3} \mathrm{~s}^{-1}$ (Ratdomopurbo et al., 2013), but this is dwarfed by the 2010 eruption, which reached a peak extrusion rate of $35 \mathrm{~m}^{3} \mathrm{~s}^{-1}$ (Surono et al., 2012; Pallister et al., 2013).

The 2010 eruption is split into 8 main stages, detailed in Komorowski et al. (2013). After one year of escalating unrest (Stage 1), the main phase of the 2010 eruption commenced with a laterally directed phreatomagmatic explosion on 26 October (Stage 2). This explosion destroyed the 2006 dome and created a new summit crater, excavating $\sim 6 \times 10^{6} \mathrm{~m}^{3}$ of non-juvenile material in the process (Surono et al., 2012; Pallister et al., 2013) and was accompanied by low fountaining pumice-rich pyroclastic flows (Drignon et al., 2014). The ash plume rose to $12 \mathrm{~km}$ altitude (Surono et al., 2012; Pallister et al., 2013) and over the next three days PDCs extended to $8 \mathrm{~km}$ from the summit (Komorowski et al., 2013). Stage 3 (29 October to 4 November) was punctuated by further explosions, unconfined dilute PDCs, and very rapid dome growth $\left(25 \mathrm{~m}^{3} \mathrm{~s}^{-1}\right)$ 
giving rise to a $\sim 5 \times 10^{6} \mathrm{~m}^{3}$ dome (Surono et al., 2012; Komorowski et al., 2013; Pallister et al., 2013). All this culminated in the Stage 4 paroxysmal 5 November eruption, which saw an 11minute sequence of laterally directed explosions producing blast-like deposits and retrogressive gravitational dome collapse (Komorowski et al., 2013) followed by an eruption plume $17 \mathrm{~km}$ high and PDCs running $16 \mathrm{~km}$ from the summit (Surono et al., 2012; Pallister et al., 2013). Approximately $10 \times 10^{6} \mathrm{~m}^{3}$ of the crater wall and $\sim 5 \times 10^{6} \mathrm{~m}^{3}$ of the erupting juvenile lava mobilized into the Gendol River valley (Pallister et al., 2013). Subsequent gravitational dome collapse (Stage 5) enlarged the crater by $400 \mathrm{~m}$ in diameter and generated confined, concentrated PDCs that continued into Stage 6 (Komorowski et al., 2013). Critically, Stage 6 PDCs were pumice and scoria-rich (Komorowski et al., 2013). As the eruption waned (Stage 7), rapid dome growth continued on 6 November with $\sim 1.5 \times 10^{6} \mathrm{~m}^{3}$ of lava extruded in less than 12 hours (a discharge rate of $35 \mathrm{~m}^{3} \mathrm{~s}^{-1}$; Surono et al. (2012); Pallister et al. (2013)). The total juvenile magma extruded during the main 2010 eruptive phases was between 30 and $60 \times 10^{6} \mathrm{~m}^{3}$, but $\mathrm{SO}_{2}$ mass balance suggests that twice this volume of magma was degassed (Surono et al., 2012).

There has been much debate on the factors that may have contributed to the uncharacteristic explosivity of the 2010 eruption. The unprecedented intensity of the 2010 eruption has been attributed to the high volumetric effusion rate or the high ascent rate of a large volume of magma (Surono et al., 2012; Costa et al., 2013; Jousset et al., 2013a; Pallister et al., 2013), and/or the complex rheological behaviour of that same volume of magma (Costa et al., 2013). Magma ascent rates in 2010 are inferred to have been significantly higher than for previous eruption (Costa et al., 2013; Preece et al., 2013), while Merapi's pre-eruptive magma reservoir has remained at the same depth $(\sim 4.5$ to $9 \mathrm{~km})$ for at least the last 100 years (Preece et al., 2014; Erdmann et al., 2016). The very rapid ascent rate of the magma between the shallow reservoir and surface likely favoured incomplete outgassing of the magma, leading to overpressure development below the pre-existing dome (Pallister et al., 2013). This is supported by mineral and glass composition data (Genareau et al., 2014) and seismic data (Jousset et al., 2013a) that suggest overpressure development prior to the 26 October (Stage 2) explosion. Magma-carbonate interaction has also been associated with $\mathrm{CO}_{2}$ release at Merapi prior to 2010 (Chadwick et al., 2007; Deegan et al., 2010) and has been suggested as a contributing factor to the unusual explosivity of the 2010 eruption (Borisova et al., 2013).

\section{Sample suite}

The samples included in this study were erupted between 1888 and 2013. The 2010 eruption samples were collected during a field campaign in August 2013 (see Komorowski et al. 
(2013) for a detailed deposit stratigraphy). We collected material from various PDC deposits on the southeastern flank of the volcano, mostly in the Gendol River valley and close to the summit (Figure 1A, Table 1). The samples were erupted during Stage 2 (26 October, 2010; phreatomagmatic explosion and low fountaining), Stage 4 (November 5, 2010; paroxysmal full dome and upper conduit explosion), and Stage 6 (pumice-bearing pyroclastic fountain collapse) of the 2010 eruption. We procured two samples from PDC deposits attributed to the 2006 eruption (location 1333; Figure 1A). Three samples from the November 18, 2013 non-magmatic, phreatic explosion were sampled within $500 \mathrm{~m}$ of the crater, hours after eruption (by S. Byrdina; Figure 1A). All samples were approximately $1000 \mathrm{~cm}^{3}$ in volume and were collected to represent the range of macroscopic textures observed in the field.

We complement our sample suite with additional dome rocks dating back to 1888 . These samples were collected by Abdurachman (1998) during his 1997 field campaign. We have rock chips from the 1888, 1909, 1940, 1948, 1954, 1955, 1957, and 1997 domes (Figure 1B) and one sample from a 1994 PDC deposit. While this sample archive is extensive in its breadth of time period, most of the samples (with the exception of the 1994 sample) are roughly $8 \mathrm{~cm}^{3}$ in volume, which is not large enough to produce the core dimensions required for permeability measurements.

\section{Methods}

\subsection{Bulk rock geochemical analysis}

To complement existing data (Abdurachman, 1998; Preece et al., 2013; Erdmann et al., 2016), bulk rock geochemistry was performed by X-ray fluorescence (XRF) on two powdered samples from the 2010 eruption. Measurements were made using a Philips PW2400 X-ray spectrometer at the Regional Analytical Centre at Saint Mary's University in Halifax, Canada.

\subsection{Porosity measurements}

For samples large enough to core, $20 \mathrm{~mm}$ diameter cores were prepared and their ends were ground flat to a nominal sample length of $40 \mathrm{~mm}$. Prior to all measurements, all samples were cleaned with water and dried in a vacuum oven at $40^{\circ} \mathrm{C}$ for at least 24 hours.

The skeletal volume of each core sample was determined using an AccuPycII 1340 helium pycnometer (EOST, Université de Strasbourg). For each core, connected gas porosity, $\phi_{g a s}$, was calculated using the geometric bulk volume, $V_{b}$, and skeletal volume, $V_{s+i}$ : 
$\phi_{g a s}=\left(1-\frac{V_{S+i}}{V_{b}}\right) \times 100 \%$. Because of their irregular geometry, the connected gas porosities of the historical (pre-2006) dome samples could not be determined by helium pycnometry. As such, connected water porosity, $\phi_{\mathrm{H}_{2} \mathrm{O}}$, was measured for selected samples using the triple weight water saturation method: $\phi_{H_{2} O}=\left(\frac{m_{w}-m_{d}}{m_{w}-m_{b}}\right) \times 100 \%$, where $m_{w}$ is the mass of the water-saturated sample measured in air, $m_{b}$ is the mass of the water-saturated sample measured in water, and $m_{d}$ is the mass of the dry sample (Guéguen and Palciauskas, 1994).

The total sample porosity, $\phi_{t}$, for all cores was calculated: $\phi_{t}=1-\frac{\rho_{b}}{\rho_{s}}$, where $\rho_{b}$ is bulk sample density and $\rho_{s}$ is the skeletal density of the sample. $\rho_{s}$ was determined for each rock type by measuring the mass and volume (using the pycnometer) of a powdered sample. Isolated porosity, $\phi_{i}$, was simply calculated: $\phi_{i}=\phi_{t}-\phi_{g a s}$.

\subsection{Permeability measurements}

Gas permeability was measured using a steady state gas permeameter (EOST, Université de Strasbourg). Once placed in the permeameter, each jacketed sample was subjected to a confining pressure of $1 \mathrm{MPa}$; the microstructure was allowed to equilibrate to this confining pressure for one hour. Nitrogen gas was passed through the sample and a pressure transducer and a flow meter recorded the upstream pressure on and the volumetric flow rate through the sample, respectively. Since the downstream pressure was atmospheric pressure, the upstream pressure (zeroed at the start of the measurement) recorded was equivalent to the differential pressure across the sample. Permeability was calculated using Darcy's Law: $k_{g a s}=\frac{Q_{b} \mu L P_{b}}{A \Delta P P_{m}}$, where $Q_{b}$ is the volumetric flow rate, $\mu$ is the viscosity of the pore fluid at the ambient temperature and pressure, $L$ is the sample length, $P_{b}$ is the pressure at which the flow meter records the volumetric flow rate, $\Delta P$ is the differential pressure across the sample, $A$ is the cross sectional area of the sample, and $P_{m}=\frac{P_{u p}+P_{\text {down }}}{2}$ is the mean pressure across the sample, where $P_{u p}$ is the upstream pressure and $P_{\text {down }}$ is the downstream pressure. To account for non-Darcian fluid behaviour within the sample, $\Delta P$ was varied and $Q_{b}$ was allowed to equilibrate at each $\Delta P$. Using these data, the permeability was corrected using the Forchheimer (for inertial effects; Whitaker (1996)) and Klinkenberg (for gas slip along the walls of the permeable network; Klinkenberg (1941)) corrections on a case-by-case basis.

\subsection{Specific surface area measurements}


The specific surface areas, $S_{B E T}$, of selected 2010 samples and of all historical dome samples were measured using Brunauer-Emmet-Teller (BET) krypton (Kr) adsorption (Brunauer et al. (1938); EOST, Universite de Strasbourg). $S_{B E T}$ was calculated by determining the amount of adsorbate gas needed to create a monomolecular layer on the sample's connected surface. Each sample was placed in a vacuum-sealed vessel (itself placed in a liquid nitrogen bath; $T=-196.15$ ${ }^{\circ} \mathrm{C}$ ) and a non-adsorbant gas (in this case, He) was introduced in pressure increments and the injected volume was recorded. For a non-adsorbant gas, volume, $V_{n a}$, is proportional to pressure. For an adsorbant gas (in this case $\mathrm{Kr}$ ), pressure is not proportional to the injected volume, $V_{a}$. The volume of gas adsorbed on the surface of the sample at each pressure increment is therefore $V_{a^{-}}$ $V_{n a}$. Assuming that the surface of the sample interacts with a monomolecular layer of adsorbent gas, the volume of this layer, $V_{m}$, is derived as a function of $V_{a^{-}} V_{n a}$ (refer to Brunauer et al. (1938) for more details) and is valid for pressures below 0.35 of the saturation pressure. The saturation pressure is the pressure at which the adsorbing gas condenses from a gas to a liquid at the temperature of the liquid nitrogen bath. For the adsorbant gas $(\mathrm{Kr})$ this is close to $250 \mathrm{~Pa}$; under the measurement conditions, the non-adsorbant gas $(\mathrm{He})$ does not condense. Specific surface area is calculated: $S_{B E T}=\frac{V_{m} \times A \times N_{A}}{m_{d} \times V_{S T P}}$, where $N_{A}$ is Avogadro's constant, $A$ is the adsorption crosssectional area of the adsorbing gas molecule, $m_{d}$ is the mass of the dry sample, and $V_{S T P}$ is the volume of one mole of adsorbate gas at standard pressure and temperature.

\subsection{Microstructural assessment}

Double polished thin sections were prepared for selected samples (Table 1) and the predominant microstructural characteristics were examined using a MIRA3 TESCAN scanning electron microscope (SEM; BRGM-Université d'Orléans-CNRS, Orléans, France).

We determined fracture densities on selected samples using the stereological technique outlined by Underwood (1970) and implemented by Wong (1985), Wu et al. (2000), and Heap et al. (2014b), amongst others. For each sample, we imaged a $36 \mathrm{~mm}^{2}$ area subdivided into 42 square subregions with $1 \mathrm{~mm}$ sides. Each of these subregions was individually imaged using the SEM and the images were stitched together to produce a high-resolution panorama. Gridlines spaced at $100 \mu \mathrm{m}$ were overlain on the panorama and microcracks that intersected these gridlines were tallied $\left(P_{L}\right)$ to determine microcrack surface area per unit volume, $S_{v}=2 P_{L}$ (in $\mathrm{mm}^{-1}$; Underwood (1970)). Fractures were categorized as either being in the groundmass or through phenocrysts (excluding microlites $<100 \mu \mathrm{m}$ long).

In the gridded panoramas described above, large patches of cristobalite were identified by their 'fish-scale' textures (Komorowski et al., 2010; Horwell et al., 2013) and these patches were 
used to calibrate a greyscale threshold on the entire image using the image processing software ImageJ (see Supplementary Materials; Figure A1). This procedure eased identification of interstitial cristobalite as well as the more obvious vesicle-filling patches. All areas selected by the threshold filter were confirmed visually and the image was manually segmented in Adobe Illustrator. This segmented image was used to tally the total area comprised by cristobalite. Cristobalite proportions reported here are normalized to the rock area only, omitting total porosity. For the same images, diktytaxitic porosities were determined by applying a mask on all pore and fracture porosities, which served to isolate the remaining porosity (see Supplementary Materials; Figure A1). For microcrack, cristobalite, and diktytaxitic porosity quantification, we assume that each $36 \mathrm{~mm}^{2}$ square area is representative of the whole sample.

\section{Results}

\subsection{Field classification of the eruptive products}

Based on field criteria (modified from Komorowski et al. (2013)), we divide all samples into three simple lithological types: Type 1, Type 2, and Type 3 (Table 2). This classification relies solely on field characteristics of the 2010 deposits including colour, texture, and relative bulk density. Type 1 samples are light to medium grey, very vesicular, and pumiceous in texture with obvious sub-rounded to rounded vesicles (Figure 2A). They are plentiful in Stage 6 (pyroclastic fountain collapse, 5 November) deposits, but also found locally in Stage 2 (phreatomagmatic explosion and low fountaining, 26 October) deposits. Type 2 clasts are ubiquitous in the 2010 deposits and are dark grey to black, variably vesicular, and crystal-rich to crystal poor (equivalent to Komorowski et al. (2013) and Charbonnier et al. (2013)'s Types 1 and 2 lithologies; Figures 2B and 2C). Type 3 samples are made conspicuous in the field by their light grey colour (Figure 2D and 2E, insets). These rocks are poorly vesicular, crystal-rich to crystalpoor, and are, by far, the least abundant rock type found in the 2010 deposits. A more detailed definition of these rock types is achieved via whole rock geochemistry, microstructural characteristics (i.e. microlite morphology, prevalence of residual glass, and void space geometry), and measured physical properties (i.e. porosity, permeability, and specific surface area) in the following sections (Table 2).

\subsection{Compositional differences between Type 2 and Type 3 basaltic andesites}

The $\mathrm{SiO}_{2}-\mathrm{K}_{2} \mathrm{O}$ relationship for Merapi eruptive products from 1930 to 2013 is presented in Figure 3. Whole rock chemistry data for samples from the 1930 to 1997 eruptions are from Abdurachman (1998), data for samples from the 2006 and 2010 eruptions are from Preece et al. 
(2013), and additional data for samples from the 2010 and 2013 eruptions are from Erdmann et al. (2016) and this study. The 1930 to 2010 data are separated into the Type 2 and Type 3 lithologies using the reported rock descriptions in Abdurachman (1998) and Preece et al. (2013). Samples from Erdmann et al. (2016) were sampled during the August 2013 field campaign (see Section 3) and were classified as Type 2 or Type 3 rocks for the purpose of this study (see Supplementary Materials).

The eruptive products over the last 85 years are compositionally consistent and classify as high-K basaltic andesites, with the exception of three high-K basalts (Figure 3A). The 2006 samples are the most compositionally evolved, with $\mathrm{SiO}_{2}$ contents restricted to 55-56 wt.\%. The 2010 and 2013 samples have $\mathrm{SiO}_{2}$ contents of 54-55 wt.\% and 53.5-54.5 wt.\%, respectively (Figure 3A). With the exception of the high-K basalts (three Type 2 samples from 1997, 1992, and 1961), all samples range between 52 and $56 \mathrm{wt} . \% \mathrm{SiO}_{2}$ (Figure 3B). There is no significant distinction between the bulk compositions of Type 2 and Type 3 samples (Figure 3B). We therefore consider the Type 2 and Type 3 samples to be compositionally equivalent, though their mineral assemblages may vary.

\subsection{Microstructure and rock physical properties}

\subsubsection{Type 1 basaltic andesites}

The Type 1 samples are the most porous, with connected gas porosity ranging from 38 to 53 vol.\% (Table 2). Their microstructure is dominated by rounded to subrounded vesicles on the order of tens of microns to millimetres (Figure 2A). These rocks contain abundant microcracked plagioclase phenocrysts. The groundmass is not obviously microcracked and, as the sample is predominantly void space, we have not determined microcrack densities for these rocks. The groundmass of these rocks is partially vitric and contains few euhedral, tabular plagioclase microlites (Figure 4A). Cristobalite is not observed (Table 1). The Type 1 permeability range is $9.3 \times 10^{-14}$ to $1.6 \times 10^{-12} \mathrm{~m}^{2}$ (Figure 5A; Table 2). Specific surface area was determined for only one Type 1 sample and is $66 \mathrm{~m}^{2} / \mathrm{kg}$ (Table 2). Isolated porosity ranges between 3.9 and 5.9 vol.\% (Table 2).

\subsubsection{Type 2 basaltic andesites}

Type 2 basaltic andesites range in texture from scoriaceous (Figure 2B) to weaklyvesicular and microcracked (Figure 2C), with connected gas porosity ranging between 10 and 31 vol.\% (Table 2). Vesicles are subrounded to rounded and vary in size from 10 microns to several 
hundred microns in the least vesicular samples (Figure 2C) and from 10 microns to several millimetres in the most scoriaceous samples (Figure 2B). Microcracks are continuous between the groundmass and phenocrysts (Figure 2C). Microcrack density in the groundmass was determined for two samples: $S_{v}=40 \mathrm{~mm}^{-1}$ for sample 10_9 and $42 \mathrm{~mm}^{-1}$ for sample 10_14. Phenocryst microcrack densities for these samples were $S_{v}=64$ and $81 \mathrm{~mm}^{-1}$, respectively.

The groundmass is partially vitric in all Type 2 samples and plagioclase microlites are abundant (Figure 4B). Microlites in the 2010 samples are needle-like (Figure 4B), which is in stark contrast to the euhedral, tabular microlites of the Type 1 samples (Figure 4A). Microlites are tabular in samples from other eruptions. Cristobalite is not observed in the Type 2 basaltic andesites (Table 1).

Type 2 samples range in permeability between $1.3 \times 10^{-14}$ to $1.8 \times 10^{-11} \mathrm{~m}^{2}$ (Figure $5 \mathrm{~A}$; Table 2). Specific surface area varies between 23 to $67 \mathrm{~m}^{2} / \mathrm{kg}$ (Table 2). Isolated porosity ranges between 1.0 and 4.0 vol.\% (Table 2).

\subsubsection{Type 3 basaltic andesites}

The Type 3 basaltic andesites are vesicular to weakly vesicular (Figure 2D and 2E), with connected gas porosity ranging from 7 to 14 vol.\% (Table 2). Vesicles are subrounded to rounded and range in size from 20 microns to several hundred microns in diameter (Figure 2D). Phenocrysts contain pervasive microcracks that generally do not extend into the groundmass (Figure 2C and 2D). The groundmass microcrack densities $\left(S_{v}\right)$ are 13 and $22 \mathrm{~mm}^{-1}$ for samples 10_25 and 10_23, respectively, which is up to three times smaller than for the Type 2 samples. Phenocryst $S_{v}$ are 68 and $91 \mathrm{~mm}^{-1}$ for samples 10_25 and 10_25, respectively, which is slightly higher than for Type 2 rocks.

Plagioclase microlites in the Type 3 samples are tabular (Figure 4C) or needle-like (Figure 4D). In some places, microlites have rounded edges and meet at triple junction melting points (Figure 4C). Glass generally fills the interstitial space between microlites but, locally, regions may be glass-free, resulting in a diktytaxitic texture (Figures $2 \mathrm{D}, 2 \mathrm{E}$, and $4 \mathrm{D}$ ). This diktytaxitic texture is manifest as regions of microlite-supported, glass-bereft groundmass (Figure 4D). These regions generally occur along vesicle rims and, at times, increase the local groundmass microporosity 7 -fold (e.g. from 2 to 14 area\%, as determined by image analysis on sample 10_22).

In this study, only Type 3 rocks contain cristobalite and the diktytaxitic textures are often associated with large patches of cristobalite. In places, cristobalite abuts and protrudes into vesicles (Figure 6A) but it can also be found in the middle of the groundmass surrounded by 
diktytaxitic textures (Figure 6A). Vesicle-filling cristobalite is identified by its diagnostic fishscale cracking texture (Figure 6B) (Deer et al., 1992). Cristobalite is also observed interstitially between microlites and is identified by characteristic 'feather-textures' (Figure 4C; Horwell et al., 2013). We assessed cristobalite content in six Type 3 samples from the 2010 and 2013 eruptions and found that cristobalite content tends to increase with increasing diktytaxitic porosity (Table 1; Figure 7A).

Type 3 samples have relatively low permeability, ranging from $1.6 \times 10^{-16}$ to $4.2 \times 10^{-14} \mathrm{~m}^{2}$ (Table 2; Figure 5A), and very high specific surface area, ranging between 69 and $1961 \mathrm{~m}^{2} / \mathrm{kg}$ (Table 2). Isolated porosity ranges between 2.6 and 6.3 vol.\% (Table 2).

\section{Discussion}

\subsection{Physical properties: Hints of microstructural complexity}

\subsubsection{Porosity and permeability}

A log-log plot of connected gas porosity versus permeability of all measured samples is shown in Figure 5A. Permeability broadly increases with increasing connected porosity, as observed in other studies on volcanic rocks (Eichelberger et al., 1986; Klug and Cashman, 1996; Mueller et al., 2005; Bernard et al., 2007; Bouvet de Maisonneuve et al., 2009; Heap et al., 2014b; Farquharson et al., 2015). Compared to the Type 2 and Type 3 samples, Type 1 rocks have relatively low permeability for their connected porosity and are described empirically by a simple power law of $k=3.4 \times 10^{-18} \phi_{\text {gas }}{ }^{3.1}$. A power law exponent of 3.1 is comparable to values for other dacitic to rhyolitic pumices (Klug and Cashman, 1996), though our fit is not well constrained $\left(R^{2}=0.19\right)$ due to the variability in permeability for any given porosity. The Type 2 data are well described by a power law relationship of $k=1.7 \times 10^{-20} \phi_{g a s}{ }^{6.0}\left(R^{2}=0.95\right)$, while the Type 3 samples are described by $k=5.6 \times 10^{-22} \phi_{g a s}{ }^{6.9}\left(R^{2}=0.52\right)$. We note that the permeability of Type 3 rocks varies more than the Type 2 samples for any given connected porosity. The power law exponents for these two rock types do not differ significantly (6.0 and 6.9) and are almost twice that reported for dacitic and rhyolitic pumices (3.5; Klug and Cashman (1996)), but approximately half of that found for edifice-forming andesites from Volcán de Colima (Mexico) (15.9; Heap et al. (2014b)), an andesitic stratovolcano of similar eruptive history to Merapi (Varley et al., 2010; Lavallée et al., 2012; Varley and Komorowski, 2015).

Much of the porosity-permeability data available to date is for rhyolitic and dacitic pumices in which the dominant microstructure is rounded vesicles separated by thin bubble walls (Eichelberger et al., 1986; Klug and Cashman, 1996; Rust and Cashman, 2004; Wright et al., 
2006; Bouvet de Maisonneuve et al., 2009; Wright et al., 2009). These rocks are similar to the Type 1 samples in this study (Figure 2A) and are in contrast to the hybrid microcrack-vesicle microstructure of the Type 2 samples and the microcrack-diktytaxitic microstructure of the Type 3 samples (Figures 2B to 2E). The Type 2 and Type 3 rocks are reminiscent of edifice-forming andesites and the high power law exponents that describe them may reflect the global role of microcracks that help construct the fluid transport networks in these rocks (Heap et al., 2014b; Farquharson et al., 2015). Small increases in connected microcrack porosities have a significant effect on permeability, creating shortcuts through which fluid can pass more easily from pore to pore (Heap et al., 2014b). However, the increased variability in the permeability of Type 3 samples (with respect to Type 2 samples) may indicate a different microstructural control on permeability. We assess this distinction in the following sections.

\subsubsection{Specific surface area and permeability}

Specific surface areas for the Merapi samples range between 16 and $1961 \mathrm{~m}^{2} / \mathrm{kg}$ (Table 3) and extend well beyond those reported for similar sample suites at Volcán de Colima (15 to 546 $\mathrm{m}^{2} / \mathrm{kg}$, Heap et al. (2014b) and Farquharson et al. (2015)). In the most extreme cases, $S_{B E T}$ is more than 3.5 times that reported by Farquharson et al. (2015). All samples with specific surface areas greater than $250 \mathrm{~m}^{2} / \mathrm{kg}$ bear diktytaxitic textures and cristobalite.

Since the historical dome samples are too small to measure permeability directly, we have chosen to model their permeability by applying a geometrical permeability model: the Kozeny-Carman relationship (Kozeny, 1927; Carman, 1937; Guéguen and Palciauskas, 1994):

$$
k_{K C}=\frac{\phi_{c}\left(r_{H}\right)^{2}}{b \tau^{2}} \quad \text { Eq. } 1
$$

where $k_{K C}$ is modelled permeability, $\phi_{c}$ is connected porosity, $b$ is a constant used to describe the permeable network geometry ( 8 for tubes, 12 for cracks; Bernabé et al. (2010)), and $\tau$ is tortuosity of the flow channel. $r_{H}$ is the hydraulic radius and can be determined using the measured specific surface area, $S_{B E T}: r_{H}=\frac{\phi_{c}}{\rho_{b} S_{B E T}}$ (Heap et al., 2014b).

First, we determined $S_{B E T}$ for six 2010 samples for which the permeability has been measured (Table 3). These six samples were chosen to represent the range of textures observed in our sample suite. Knowing the permeability of these rocks, Eq. 1 can be solved for sample tortuosity, $\tau$ :

$$
\tau^{2}=\frac{\phi_{c}{ }^{3}}{k_{K C} b \rho_{b}{ }^{2} S_{B E T}{ }^{2}} \quad \text { Eq. } 2
$$

where $b=8$ or 12 (Table 3 ). We assume that these tortuosity values are typical of all samples with similar microstructure; for instance, we assume that the tortuosity of a Type 3 sample (e.g. sample 
10_22, Table 3) is roughly the same for all Type 3 samples. We therefore assign these known tortuosity values to texturally similar historical dome samples (Table 3); we discuss the significance of these tortuosity values below. Using these values of $\tau$, we solve Eq. 1 for the permeability, $k_{K C}$, of the historical dome samples using $b=8$ and $b=12$ (Table 3). The KozenyCarman relationship, thus, provides an elegant means of estimating the permeability of samples whose irregular geometry prevents direct measurement.

As has been pointed out by some authors, the Kozeny-Carman relationship is not always appropriate for volcanic rocks, especially those with vesicle-controlled permeability (Klug and Cashman, 1996; Mueller et al., 2005). In addition, 'microporosity' introduces both high specific surface area and high tortuosity and is considered to not significantly impact permeability (Saar and Manga, 1999; Wright et al., 2006; Farquharson et al., 2015). In theory, a tortuosity value of 1 denotes a straight path; the value of tortuosity increases with increasing path complexity. However, tortuosity values $<1$ have been calculated for andesitic rocks using the Kozeny-Carman relationship and measured specific surface areas (Heap et al., 2014b; Farquharson et al., 2015). This suggests that the simple geometrical assumptions (crack or tube fluid pathways) made in the Kozeny-Carman relationship are incomplete and the relationship may be ill equipped as a predictive model of permeability in rocks with complex microstructure (Heap et al., 2014b; Farquharson et al., 2015). However, microstructural investigation of the Merapi historical dome samples shows them to be predominantly microcracked suggesting that their permeability is strongly microcrack-controlled. Of these samples, only three are confirmed to have diktytaxitic textures and, therefore, high microporosity (Table 3).

We note that all our calculated tortuosity values are less than 1 (Table $3 ; b=12$ ). While diktytaxitic textures persist in our Type 3 samples and, thus, impact sample tortuosity in profound ways, we use tortuosity exclusively as a calibration term for calculating the permeability of samples of irregular shape. We do not contend that the tortuosity values calculated in this study describe the tortuosity of the fluid pathways through the rock in any meaningful physical way. Instead, it is perhaps better to think of them as empirical constants that reflect the more complex fluid path geometry.

The modelled permeability values show that the geometry of the fluid channel ( $b=8$ or $b=12$ ) does not significantly change the modelled permeability (Table 3); owing to the abundance of microcracks in these samples, we restrict our discussion to $b=12$. Figure 5B shows a plot of permeability as a function of specific surface area for the six samples for which both permeability and specific surface area were independently measured, as well as for the nine historical dome samples for which permeability is inferred using the Kozeny-Carman relationship. Generally, the 
Type 3 samples have higher specific surface areas (and correspondingly lower permeabilities) than the Type 2 samples. The single Type 1 sample falls within the region populated by the Type 2 basaltic andesites.

We observe that the measured and predicted Type 2 and Type 3 permeability values form two unique groups (Figure 5C): i) one that defines a power law trend $\left(k=1.8 \times 10^{-19} \phi_{\text {gas }}{ }^{5.3}\right.$; $\left.R^{2}=0.98\right)$ and is predominantly made up of Type 2 samples, and ii) one that deviates from this trend, generally aligning with Type 3 samples (Figure 5C, red symbols). This first group displays no diktytaxitic textures; the microstructure is characterized by a pervasive microcrack network. The second, deviant population is characterized by the presence of diktytaxitic textures suggesting a diktytaxitic influence on permeability, which is discussed hereafter.

\subsection{Cristobalite- and diktytaxitic texture-controls on permeability}

In this study, the samples with the highest specific surface areas and lowest permeabilities are the Type 3 basaltic andesites (Figure 5B). With the exception of three historical dome samples, these rocks all contain conspicuous diktytaxitic textures and cristobalite (Figure 5C). Vesicle-filling, fish-scale cristobalite is always associated with diktytaxitic textures (Figure 6A), but interstitial cristobalite is also observed between microlites (Figures 6A and 6B).

Cristobalite is a high temperature, low-pressure silica polymorph (Deer et al., 1992; Heaney, 1994) and, under volcanic conditions, may form via: i) vapour deposition from a Si-rich volatile phase (Boudon et al., 1998; Baxter et al., 1999; de Hoog et al., 2005; Komorowski et al., 2010; Horwell et al., 2013); ii) devitrification of volcanic glass after emplacement (Ewart, 1971; Swanson et al., 1989; Baxter et al., 1999; Horwell et al., 2013); or iii) crystallisation out of a silica-rich melt phase at low pressure and high temperature (Martel, 2012; Schipper et al., 2015). The provenance of the silica has been proposed as being either local (i.e. the interstitial glass; Horwell et al. (2013); Schipper et al. (2015)) or from deep within the magmatic system, where silica-bearing gases transport silica to more favourable deposition locations in the dome (de Hoog et al., 2005; Horwell et al., 2013). Large patches of fish-scale cristobalite protruding into vesicles are often interpreted as being vapour deposited (de Hoog et al., 2005), whereas groundmass feather-textures are taken as evidence of glass devitrification (Horwell et al., 2013). The effect of cristobalite on permeability has, thus far, not been fully characterized.

In this study, the range of connected porosity for the cristobalite-bearing samples is narrow and varies between 7 and 14 vol.\%, while permeability spans three orders of magnitude (between $5.2 \times 10^{-17}$ and $4.2 \times 10^{-14} \mathrm{~m}^{2}$; Figure 7B). Critically, we observe that both cristobalite content and diktytaxitic porosity tend to increase with increasing permeability in these samples, 
though these values may vary significantly for any given permeability (e.g. $k \sim 10^{-14} \mathrm{~m}^{2}$; Figure 7C).

The cristobalite and associated diktytaxitic textures in our samples bear a strong resemblance to vesicle rims observed in samples from Cordón Caulle (Chile) (Schipper et al., 2015), Santiguito (Guatemala), and Mount St. Helens (USA) (see Figure 4.14 of Damby (2012)), which are interpreted as evidence of sub-solidus groundmass interaction with corrosive fluids (Damby, 2012; Schipper et al., 2015). Alternatively, de Hoog and van Bergen (2000) and de Hoog et al. (2005) propose that diktytaxitic textures may be produced by gas filter pressing (Anderson et al., 1984; de Hoog and van Bergen, 2000; Pistone et al., 2015). In their model, vapour-saturated crystallisation of the groundmass gives rise to a pressure gradient between the groundmass and the surrounding vesicles. This pressure gradient forces the volatile-saturated melt phase from between the crystals and into the vesicles, where it crystallizes a diverse crystal assemblage (i.e. feldspars, pyroxenes, Fe-Ti oxides, cristobalite, and zirconolite; de Hoog and van Bergen (2000)) and significantly reduces vesicle size (see Figure 1, de Hoog et al. (2005)).

Critically, cristobalite-associated diktytaxitic textures have been demonstrated during closed-system, isothermal decompression experiments on water-saturated silica-rich melts (Martel, 2012). In sample D6 of Martel (2012) (see Figure 6D of that study and Figures 6C and $6 \mathrm{D}$ of this study), the groundmass is largely microlite-supported with large patches of fish-scale cristobalite protruding into vesicles (Figure 6C); there is interstitial glass only where the cristobalite patches are rooted to the vesicle walls. The close resemblance between the Merapi Type 3 textures (Figures 6A and 6B) and the experimentally-derived textures (Martel, 2012; Figures 6C and 6D) suggests that cristobalite-associated diktytaxitic textures do not necessarily require the presence of corrosive fluids (Damby, 2012; Schipper et al., 2015) nor a late-stage crystallisation event as described by de Hoog and van Bergen (2000).

Based on our observations and the experiments of Martel (2012), we modify de Hoog and van Bergen's (2000) hypothesis by proposing that vapour-saturated crystallisation of the groundmass microlites (including plagioclase, pyroxene, and Fe-Ti oxide microlites) gives rise to an overpressure (Tait et al., 1989; Sparks, 1997) sufficient to expunge the remaining silica-rich melt through the groundmass microlite network and into surrounding vesicles. It is from this silica-rich melt that cristobalite is precipitated (Martel, 2012; Schipper et al., 2015). We propose that this gas filter pressing event may result in significant textural changes to the overall rock, namely the creation of diktytaxitic textures (de Hoog and van Bergen, 2000; Pistone et al., 2015).

The formation of cristobalite and diktytaxitic textures results in significant microstructural modification (Figure 6) that may profoundly impact rock permeability. The 
location of the silica source and the mechanism of cristobalite formation are integral to how the pore space is modified. Vapour-deposition of silica sourced at depth introduces excess material into the dome rock and likely reduces permeability (Wright et al., 2011; Horwell et al., 2013). In these cases, silica is transported up from deep within the magmatic plumbing as $\mathrm{SiF}_{4}$ and, as pressure decreases, $\mathrm{SiO}_{2}$ preferentially exsolves from the volatile phase and crystallizes (de Hoog et al., 2005). High concentrations of fluorine at depth are required to dissolve sufficient silica for deposition in the dome, and there is some evidence that crystallization of F-rich minerals accompanies cristobalite formation (de Hoog et al., 2005). Transport of silica by $\mathrm{SiF}_{4}$ is compelling in high-K volcanic systems (such as Merapi) (de Hoog et al., 2005) since these systems are often enriched in fluorine (Edgar et al., 1994). Alternatively, moderate temperature variations $\left(\sim 100^{\circ} \mathrm{C}\right)$ and higher $\mathrm{SiF}_{4} / \mathrm{HF}$ ratios in domes than at depth can redistribute silica locally within domes (de Hoog et al., 2005).

If, however, the diktytaxitic textures form by gas filter pressing in a hot dome, the opening of the interstitial space between microlites must partially offset the occultation of vesicles by cristobalite crystallisation. This local redistribution of silica may not significantly change the total porosity of the rock, but may alter permeability by rearranging the pore network. A similar effect may result from groundmass devitrification. Critically, gas filter pressing necessitates microlite crystallisation and the melt phase must be above its glass transition temperature. Cristobalite and diktytaxitic porosity formation must therefore occur in a hot dome. Once the dome has cooled sufficiently or has completely degassed, cristobalite formation is more likely a result of vapour transport and/or matrix devitrification.

In contrast to observations that vapour precipitated minerals in volcanic rocks contribute to a notable decrease in rock permeability (Wright et al., 2011), our data suggests that cristobalite content and permeability are positively correlated, though cristobalite content varies greatly for any given permeability (Figure 7C). We cannot discount cristobalite formation by vapour deposition in our samples. Rocks with initially higher connected porosity have the potential to harbour more vapour-precipitated cristobalite; this may explain the positive correlation between cristobalite content and permeability. However, cristobalite content also increases with increasing diktytaxitic porosity (Figure 7A), which, with the support of decompression experiments (Martel, 2012), suggests a relationship between their formations. The diktytaxitic textures result in more tortuous pathways for fluid flow (in comparison to open vesicles), but remain permeable. The cristobalite-diktytaxitic relationship (Figure 7A) likely reflects a gas filter pressing mechanism polluted by subsequent vapour deposition of cristobalite once the dome rock has cooled. 


\subsection{Microstructural controls on permeability}

Having considered the microstructure of the Types 1, 2, and 3 rocks, we revisit the dominant microstructural controls on permeability. While convenient, simple empirical power laws do not offer insight into the physics governing permeability and should, therefore, not be taken as robust predictive models. However, changes in power law trends within datasets should signal changes in the dominant microstructural controls on permeability (Bernard et al., 2007; Heap et al., 2014b; Farquharson et al., 2015). Recent work by Heap et al. (2014b) and Farquharson et al. (2015) proposes that the porosity-permeability data of andesitic rocks from Volcán de Colima are better described using two power laws, as opposed to one. To do this, Farquharson et al. (2015) applied a piecewise linear regression to identify a critical connected porosity, dubbed the 'porosity changepoint', at which their data exhibit a change in behaviour; they modelled the data above and below this value using two different power laws. Subsequently, they employed a Bayesian Information Criterion (BIC) approach (Main et al., 1999), which penalizes models of increased complexity (i.e. two power laws being more complex than one) and statistically determines if, despite this penalty, the data are best described using a more complex model. The modified BIC approach is independent of the piecewise linear regression used to determine the changepoint value. For andesites from Volcán de Colima, the porosity-permeability relationship exhibits a change in behaviour at a connected porosity of $15 \mathrm{vol} . \%$ (Farquharson et al., 2015). This statistically significant change in power law exponent is attributed to the predominance of microcrack-controlled permeability at porosities below $15 \mathrm{vol} \%$ and vesiclecontrolled permeability at porosities above this threshold. A statistically-viable changepoint has also been observed in a suite of variably-welded PDC deposits from Mount Meager, Canada (Heap et al., 2015). In these rocks, a high power law exponent above a connected porosity of 15.5 vol.\% is explained in terms of the closure of wide ( 200-300 $\mu \mathrm{m})$ inter-granular flow channels during viscous densification; a low exponent below 15.5 vol.\% is explained by flow through narrow $(\sim 50 \mu \mathrm{m})$ channels that are abundant enough to allow porosity loss without considerable permeability reduction.

To assess whether a changepoint exists in our connected porosity-permeability data, we apply the modified BIC approach to our Type 2 and Type 3 basaltic andesites (see Farquharson et al. (2015) and Main et al. (1999) for details). We exclude Type 1 samples since this approach is used to assess continuous functions only (Main et al., 1999). We find that piecewise linear regression does not identify any statistically viable changepoint porosity for our data.

We combine our data with those from studies of basaltic andesitic to andesitic lavas from Volcán de Colima and Montagne Pelée (Martinique) for which the connected porosity, $\varphi_{c}$, of the 
measured samples is explicitly given (Figure 8; Jouniaux et al. (2000); Bernard et al. (2007); Kolzenburg et al. (2012); Kendrick et al. (2013); Heap et al. (2014b); Farquharson et al. (2015)). Although more felsic in composition $-\mathrm{SiO}_{2}$ ranges between 58 and 61\% (Bernard et al., 2007; Farquharson et al., 2015) - the microstructure of these rocks is similar to those of this study (see Figure 8 of Farquharson et al. (2015)). Phenocryst content does not vary considerably between studies; reported phenocryst contents are 44\% for Montagne Pelée (Jouniaux et al., 2000), 30\% for Volcán de Colima (Kendrick et al., 2013; Heap et al., 2014b), and 30-55 vol.\% for Merapi (Erdmann et al., 2016). As there are no obvious discontinuities in the combined dataset (i.e. no obvious breaks or gaps in the data; Figure 8), we now include all Type 1 samples in our analysis. Applying a single empirical power law to the amalgamated dataset, we find $k=5.1 \times$ $10^{-19} \phi_{c}{ }^{4.0}\left(R^{2}=0.67\right)$. This relationship approaches that proposed for other dome-forming rocks (Mueller et al., 2005). We note that the data are not well constrained by this power law below $\varphi_{c}=10 \mathrm{vol} . \%$ (Figure 8). This is due to outlying samples below $\varphi_{c}=5 \mathrm{vol} . \%$ that may deviate from a simple microstructural control on permeability; these data are omitted for the BIC analysis of the combined dataset.

Piecewise linear regression of the data suggests that applying three power laws is warranted for all data above $\varphi_{c}=5 \mathrm{vol} . \%$ and modified BIC analysis confirms the statistical existence of two changepoints at $\varphi_{c}=10.5$ and 31 vol.\% (Figure 8). Modifying the changepoint values manually did not improve the BIC. We emphasize that the changepoint method is a statistical treatment of the data and is independent of texture. While changepoint porosities may reflect changes in microstructure, it is more instructive to think of these transitions as 'change zones' (Heap et al., 2015) over which one dominant microstructure transitions to another dominant microstructure.

We divide the porosity-permeability data into four domains (Figure 8). Domain 1 concerns rocks with connected porosity below 5 vol.\% for which the microtextural control on permeability is unclear. Domain 2 spans connected porosities between $5<\varphi_{c}<10.5$ vol.\% and the data are described by a power law: $k=2.8 \times 10^{-30} \phi_{c}{ }^{15.1}$. The rocks in this domain (for which we have performed a detailed microstructural assessment) classify as Type 3 and have few vesicles that may facilitate fluid flow, forcing fluids to travel through the narrow microcracks and tortuous diktytaxitic porosity (Figures 2D and 2E; see sample B5 of Heap et al., (2014)). The other Type 3 samples in this study fall into Domain 3 (Figure 8, yellow circles), but when considered as a group they do not follow the power law trend defined for this domain (Figure 8, shaded yellow). While the isolated porosity of these rocks is, on average, larger than that of the Type 2 samples, it is unclear how this volume is partitioned between isolated pores and 
diktytaxitic porosity (Figures 2E). The fluid pathways formed by these diktytaxitic textures may not considerably improve the efficacy of fluid flow (Saar and Manga, 1999; Wright et al., 2006; Farquharson et al., 2015) but we emphasize that increasing diktytaxitic porosity is associated with increasing cristobalite content and rock permeability (Figure 7B). Interestingly, texturally similar samples are reported in andesites from Volcán de Colima (Figure 2C of Heap et al. (2014b); Figure 8C of Farquharson et al. (2015)) and Mt. Ruapehu (New Zealand; Heap and Kennedy (2016)), hinting to a ubiquity of diktytaxitic textures in andesitic stratovolcano dome rocks. Diktytaxitic porosity must contribute to the overall rock permeability however, at present, we cannot ascertain its relative importance nor decouple the microcrack- and diktytaxitic-controls on permeability.

Overall, the low permeability of the Type 3 rocks is related to their low connected porosity, confirmed in thin section by a general absence of groundmass microcracks and vesicles compared with Type 1 and Type 2 rocks. The connected porosity-permeability data for these rocks are likely controlled by densification and post-emplacement alteration; these are textural changes that characterize the post-eruption life of the rocks. The low porosity of these rocks could be explained by prolonged exposure to high temperature. High temperatures will lower the melt viscosity, promoting volatile escape and efficient densification through viscous sintering of the groundmass (Vasseur et al., 2013; Okumura and Sasaki, 2014; Heap et al., 2015), thus modifying the pore structure such that the passage of fluids is dominantly controlled by microcracks. Additionally, the singular occurrence of cristobalite in these rocks suggests alterations to their microstructure that, depending on the mechanism of cristobalite formation, may decrease permeability (Wright et al., 2011). Diktytaxitic textures introduce a high tortuosity to the fluid path. This, in itself, may not significantly impact the overall permeability of the rock at the sample scale but if its formation is related to cristobalite formation, diktytaxitic textures may offset the vesicle occultation of cristobalite. The mechanism of cristobalite crystallisation must fundamentally impact the rock microstructure and, thus, rock permeability, but concomitant creation of diktytaxitic porosity likely dampens the permeability-reducing effect of cristobalite. Based on the positive correlation between cristobalite content and diktytaxitic porosity in our samples, we contend that the permeability of rocks in Domain 2 is microcrack- and diktytaxiticcontrolled.

Domains 2 and 3 are separated by a changepoint of $\varphi_{c}=10.5$ vol.\% and Domain 3 is best described by a power law fit of $k=7.5 \times 10^{-21} \phi_{c}{ }^{5.8}$ (Figure 8). The majority of rocks in Domain 3 have significant vesicle porosity and no diktytaxitic textures (Type 2; Figures $2 \mathrm{~B}$ and $2 \mathrm{C})$. We attribute the dominant permeability control in these rocks to microcrack- and vesicle- 
porosity where vesicles form a more complete flow path and passing fluids only occasionally rely on microcrack connections.

Domain 4 , beginning at $\varphi_{c}=31 \mathrm{vol} . \%$, is predominantly associated with pumiceous samples (Figure 8). In these rocks, fluids travel through a connected vesicle network. While the power law describing this final domain predicts decreasing permeability with increasing connected porosity $\left(k=1.9 \times 10^{-9} \phi_{c}{ }^{-1.9}\right)$, we hazard that this is an artefact of our dataset, which is limited to connected porosities below 63 vol.\% and, therefore, highly vesicular pumiceous samples are under-represented. Indeed, studies on pumice confirm that porosity and permeability are positively correlated (Eichelberger et al., 1986; Klug and Cashman, 1996; Rust and Cashman, 2004; Wright et al., 2006; Bouvet de Maisonneuve et al., 2009; Wright et al., 2009). Our model is, therefore, not well constrained in Domain 4.

The connected porosity-permeability trends presented here represent only a portion of the permeability life cycle of volcanic rocks. Processes that dominate pore space construction in the conduit (bubble expansion and coalescence (Martel and Iacono-Marziano, 2015; Kennedy et al., 2016), shear induced fracture (Cordonnier et al., 2012; Lavallée et al., 2013)) may not be preserved, particularly in Domain 2 whose rocks have had time to lose their volatiles. In this domain, fractures are more efficient pathways for fluid flow, meaning that small increases in connected porosity result in large changes in permeability (Heap et al., 2014). Data in Domains 3 and 4 show that the same increases in connected porosity result in less permeability increase than for rocks in Domain 2. These data reflect only a part of the permeability hysteresis expected in volcanic rocks (e.g. Rust and Cashman (2004); Wright et al. (2009); Cashman and Sparks (2013); Heap et al., 2014b Heap et al. (2014a)).

\section{Implications for Merapi's eruptive dynamics}

Here we assess the contribution of a so-called 'impermeable' plug to overpressure development prior to the 2010 eruption and its possible implication for explosivity. Based on our extensive sample suite, the Type 3 basaltic andesites are the best candidates for a lowpermeability material capable of restricting outgassing. They are the least permeable of the rocks investigated and display characteristics of being non-juvenile. This is supported by the presence of rounded microlite edges and triple junction melting points (Figure 4C), which suggest an episode of reheating. Further, lower groundmass microcrack densities suggest that the Type 3 rocks had sufficient time to degas and densify via microcrack-healing and viscous pore collapse (Vasseur et al., 2013; Heap et al., 2015), significantly reducing their permeability (Figure 5A). 
They contain abundant cristobalite, the formation of which may require as much as 48 hours at high temperature and low pressure (Martel, 2012).

In particular, we interpret the 2010 Type 3 basaltic andesites as fragments of the 2006 terminal dome. The microlites found in these rocks are tabular and resemble microlites found in the 2006 Type 2 basaltic andesites (Preece et al., 2013). Cristobalite-associated diktytaxitic textures require the magma to dwell at low pressure and high temperature for an extended period of time, suggesting a prolonged cooling period (Martel, 2012). We propose that this material cooled between 2006 and 2010 and was reheated and remobilized by the 2010 juvenile magma (Types 1 and 2). Similarly, we suggest that the 2013 Type 3 basaltic andesites represent the 2010 terminal dome that grew from 5 to 8 November, 2010 (Stage 7). This interpretation is buttressed, in part, by the presence of needle-like microlites in both 2013 Type 3 and 2010 Type 2 samples (Figures 4B and 4D).

Typically, Type 3 basaltic andesites have been the most abundant rock type identified at Merapi, making up between 34 and 84 vol.\% of PDC deposits between 1930 and 1994 (Abdurachman, 1998). In the 2010 PDC deposits, only 4\% of the erupted material was Type 3 basaltic andesite (Charbonnier et al., 2013). Considering the total volume of the erupted juvenile material in 2010, Type 3 rocks make up between $1.3 \times 10^{6}$ and $2.5 \times 10^{6} \mathrm{~m}^{3}$ of all erupted products during that eruption. Assuming that the Type 3 basaltic andesites represent relict dome material, this volume is within the range of lava dome volumes determined for previous VEI 2 eruptions dating back to 1976 (between $0.9 \times 10^{6} \mathrm{~m}^{3}$ (1976) and $6.8 \times 10^{6} \mathrm{~m}^{3}$ (1992); Voight et al. (2000)). Indeed, the maximum lava dome volume prior to the June 2006 eruption was $4.1 \times 10^{6} \mathrm{~m}^{3}$ (Charbonnier and Gertisser, 2008), approximately two times larger than the volume of Type 3 rocks expunged in 2010. This suggests that the pre-eruptive dome volume does not change significantly from eruption to eruption and is unlikely to contribute to abnormal overpressure development prior to eruption. Indeed, we consider the Type 3 basaltic andesites to represent a low-permeability cap left in place at the end of every dome-forming eruption. While the generation of an overpressure prior to the 2010 eruption has been established (Genareau et al., 2014), we suggest that overpressure development due to a low-permeability dome is in no way unique to this particular eruption and, therefore, cannot be cited as a contributing factor to its unusual explosivity. The debate on the reasons for the high explosivity of the 2010 eruption remains open.

\section{Conclusions}


Generally, the permeability of volcanic rocks increases with increasing connected porosity. The porosity-permeability data presented herein for basaltic andesites from Merapi do not suggest a dominant microstructural control on permeability. However, when combined with data from similar andesitic and basaltic andesitic volcanoes, we observe two threshold porosities, $\varphi_{c}=10.5$ and $31 \mathrm{vol} . \%$, that signal the transitions from microcrack-and diktytaxitic-controlled to vesicle-and microcrack-controlled permeability and from vesicle-and microcrack-controlled to vesicle-controlled permeability, respectively. The least permeable rocks at Merapi are the Type 3 basaltic andesites, which we interpret as fragments of terminal domes, emplaced at the end of every eruption prior to quiescence. In particular, these rocks are characterized by prevalent diktytaxitic textures and cristobalite. We propose that these textures result from gas filter pressing occurring high in the conduit, which evacuates the Si-rich interstitial melt into surrounding vesicles. We speculate that cristobalite is crystallized from this Si-rich liquid, significantly modifying the rock microstructure and that the contemporaneous formation of tortuous diktytaxitic porosity moderates the permeability-reducing potential of cristobalite.

While these low-permeability rocks are abundant in most eruption deposits at Merapi, they are the least abundant lithology in the 2010 deposits. Despite this, the total volume of Type 3 rocks erupted in 2010 is comparable to the estimated dome volumes preceding VEI 2 eruptions. This is a testament to the sheer volume of juvenile material erupted during the 2010 eruption. We conclude that while the Type 3 lithology must contribute to overpressure development prior to eruptions of Merapi, it did not significantly impact the explosivity of the 2010 eruption.

\section{Acknowledgements}

Funding for research costs was provided by the ANR project DoMerapi (ANR-12-BS060012). Additional funding for A.R.L. Kushnir was provided by a Postgraduate ScholarshipDoctoral (CGS D3) provided by the Natural Sciences and Engineering Research Council of Canada (NSERC) (number CGSD3-444207-2013). M.J. Heap acknowledges IDEX Attractivité grant ("VOLPERM"), funded by the Université de Strasbourg. We thank S. Byrdina for collecting and providing us with the 2013 samples. We acknowledge J. I. Farquharson for discussions and for his role in the development and maintenance of the benchtop permeameter at EOST (Strasbourg). F. Wang is acknowledged for measuring the connected porosities of the Type 1 samples used in this study. I. Di Carlo is thanked for SEM assistance. S. Janiec and P. Benoist are acknowledged for thin section preparation. We extend our sincere thanks to J. Marti for acting as editor and to H. M. N. Wright and an anonymous reviewer for their insightful comments, which helped to clarify the manuscript. 


\section{References}

Abdurachman, E.K., 1998. Géologie des produits de l'activité historique et contribution à l'évaluation des risques au Merapi (Java), Indonésie, Université d'Orléans, Orléans, 289 pp.

Abdurachman, E.K., Bourdier, J.-L. and Voight, B., 2000. Nuées ardentes of 22 November 1994 at Merapi volcano, Java, Indonesia. Journal of Volcanology and Geothermal Research, 100: 345-361.

Anderson, A.T., Swihart, G.H., Artioli, G. and Geiger, C.A., 1984. Segregation vesicles, gas filter pressing, and igneous differentiation. Journal of Geology, 92(1): 55-72.

Ball, J.L., Stauffer, P.H., Calder, E.S. and Valentine, G.A., 2015. The hydrothermal alteration of cooling lava domes. Bulletin of Volcanology, 77(12).

Baxter, P.J., Bonadonna, C., Dupree, R., Hards, V.L., Kohn, S.C., Murphy, M.D., Nichols, A., Nicholson, R.A., Norton, G., Searl, A., Sparks, R.S.J. and Vickers, B.P., 1999.

Cristobalite in volcanic ash of the Soufriere Hills Volcano, Montserrat, British West Indies. Science(283): 1142-1145.

Bernabé, Y., Li, M. and Maineult, A., 2010. Permeability and pore connectivity: A new model based on network simulations. Journal of Geophysical Research-Solid Earth, 115.

Bernard, M.-L., Zomara, M., Géraud, Y. and Boudon, G., 2007. Transport properties of pyroclastic rocks from Montagne Pelée volcano (Martinique, Lesser Antilles). Journal of Geophysical Research, 112: doi:10.1029/2006JB004385.

Blundy, J. and Cashman, K., 2001. Ascent-driven crystallisation of dacite magmas at Mount St Helens, 1980-1986. Contributions to Mineralogy and Petrology, 140(6): 631-650.

Borisova, A.Y., Martel, C., Gouy, S., Pratomo, I., Sumatri, S., Toutain, J.-P., Bindeman, I.N., de Parseval, Metaxian, J.-P. and Surono, 2013. Highly explosive 2010 Merapi eruption: Evidence for shallow-level crustal assimilation and hybrid fluid. Journal of Volcanology and Geothermal Research, 261: 193-208.

Boudon, G., Balcone-Boissard, H., Villemant, B. and Morgan, D.J., 2015. What factors control superficial lava dome explosivity? Scientific Reports, 5.

Boudon, G., Villemant, B., Komorowski, J.-C., Ildefonse, P. and Semet, M.P., 1998. The hydrothermal system at Soufriere Hills volcano, Montserrat (West Indies): Characterization and role in the ongoing eruption. Geophysical Research Letters, 25: 3693-3696.

Bourbié, T. and Zinszner, B., 1985. Hydraulic and acoustic properties as a function of porosity in Fontainbleau sandstone. Journal of Geophysical Research-Solid Earth and Planets, 90(NB13): 1524-1532.

Bouvet de Maisonneuve, C., Bachmann, O. and Burgisser, A., 2009. Characterization of juvenile pycroclasts from the Kos Plateau Tuff (Aegean Arc): insights into the eruptive dynamics of a large rhyolitic eruption. Bulletin of Volcanology, 71: 643-658.

Brunauer, S., Emmett, P.H. and Teller, E., 1938. Adsorption of gases in multimolecular layers. Journal of the American Chemical Society, 60: 309-319.

Carman, P.C., 1937. Fluid flow through granular beds, Transactions, Institution of Chemical Engineers, London, pp. 150-166.

Cashman, K.V. and Sparks, R.S.J., 2013. How volcanoes work: A 25 year perspective. Geological Society of America Bulletin, 125(5-6): 664-690.

Chadwick, J.P., Troll, V.R., Ginibre, C., Morgan, D., Gertisser, R., Waight, T.E. and Davidson, J.P., 2007. Carbonate assimilation at Merapi Volcano, Java, Indonesia: insights from crystal isotope stratigraphy. Journal of Petrology, 48: 1793-1812.

Charbonnier, S.J., Germa, A., Connor, B.B., Gertisser, R., Preece, K., Komorowski, J.-C., Lavigne, F., Dixon, T. and Connor, L., 2013. Evaluation of the impact of the 2010 
pyroclastic density currents at Merapi volcano from high-resolution satellite imagery, field investigations and numerical simulations. Journal of Volcanology and Geothermal Research, 261: 295-315.

Charbonnier, S.J. and Gertisser, R., 2008. Field observations and surface characteristics of pristine block-and-ash flow deposits from the 2006 eruption of Merapi Volcano, Java, Indonesia. Journal of Volcanology and Geothermal Research, 177(4): 971-982.

Clarke, A.B., Voight, B., Neri, A. and Macedonio, G., 2002. Transient dynamics of vulcanian explosions and column collapse. Nature, 415(6874): 897-901.

Cordonnier, B., Caricchi, L., Pistone, M., Castro, J., Hess, K.U., Gottschaller, S., Manga, M., Dingwell, D.B. and Burlini, L., 2012. The viscous-brittle transition of crystal-bearing silicic melt: Direct observation of magma rupture and healing. Geology, 40(7): 611-614.

Costa, F., Andreastuti, S., de Maisonneuve, C.B. and Pallister, J., 2013. Petrological insights into the storage conditions, and magmatic processes that yielded the centennial 2010 Merapi explosive eruption. Journal of Volcanology and Geothermal Research, 261: 209-235.

Damby, D.E., 2012. From Dome to Disease: The Respiratory Toxicity of Volcanic Cristobalite, Durham University, Durham.

de Hoog, J.C.M. and van Bergen, M.J., 2000. Volatile-induced transport of HFSE, REE, Th and $\mathrm{U}$ in arc magmas: evidence from zirconolite-bearing vesicles in potassic lavas of Lewotolo volcano (Indonesia). Contributions to Mineralogy and Petrology, 139(4): 485502.

de Hoog, J.C.M., van Bergen, M.J. and Jacobs, M.H.G., 2005. Vapour-phase crystallisation of silica from SiF4-bearing volcanic gases. Annals of Geophysics, 48(4-5): 775-785.

Deegan, F.M., Troll, V.R., Freda, C., Misiti, V., Chadwick, J.P., McLeod, C.L. and Davidson, J.P., 2010. Magma-Carbonate Interaction Processes and Associated CO2 Release at Merapi Volcano, Indonesia: Insights from Experimental Petrology. Journal of Petrology, 51: 1027-1061.

Deer, W.A., Howie, R.A. and Zussman, J., 1992. An Introduction to the Rock-Forming Minerals. Longman Scientific and Technical, Harlow.

Degruyter, W., Bachmann, O. and Burgisser, A., 2010. Controls on magma permeability in the volcanic conduit during the climactic phase of the Kos Plateau Tuff eruption (Aegean Arc). Bulletin of Volcanology, 72: 63-74.

Diller, K., Clarke, A.B., Voight, B. and Neri, A., 2006. Mechanisms of conduit plug formation: Implications for vulcanian explosions. Geophysical Research Letters, 33(20): 6.

Drignon, M., Arbaret, L., Burgisser, A., Komorowski, J.-C., Martel, C. and Raditya, P., 2014. Transition from effusive to explosive activity during lava dome eruption: The example of the 2010 Merapi Volcano (Java, Indonesia), American Geophysical Union Fall Meeting, San Fransisco, pp. V51B-4759.

Edgar, A.D., Lloyd, F.E. and Vukadinovic, D., 1994. The role of fluorine in the evolution of ultrapotassic magmas. Mineralogy and Petrology, 51(2-4): 173-193.

Eichelberger, J.C., Carrigan, C.R., Westrich, H.R. and Price, R.H., 1986. Non-explosive silicic volcanism. Nature, 323: 598-602.

Erdmann, S., Martel, C., Pichavant, M., Bourdier, J.L., Champallier, R., Komorowski, J.-C. and Cholik, N., 2016. Constraints from phase equilibrium experiments on pre-eruptive storage conditions in mixed magma systems: a case study on crystal-rich basaltic andesites from Mount Merapi, Indonesia. In revision.

Ewart, A., 1971. Chemical changes accompanying spherulitic crystallization in rhyolitic lavas, Central Volcanic Region, New Zealand. Mineralogical Magazine, 38: 424-434.

Farquharson, J., Heap, M.J., Baud, P., Reuschlé, T. and Varley, N., 2016. Pore pressure embrittlement in a volcanic edifice. Bulletin of Volcanology, 78(6): 1-19. 
Farquharson, J., Heap, M.J., Varley, N.R., Baud, P. and Reuschlé, T., 2015. Permeability and porosity relationships of edifice-forming andesites: A combined field and laboratory study. Journal of Volcanology and Geothermal Research, 297: 52-68.

Gaunt, H.E., Sammonds, P.R., Meredith, P.G., Smith, R. and Pallister, J.S., 2014. Pathways for degassing during the lava dome eruption of Mount St. Helens 2004-2008. Geology, 42(11): 947-950.

Genareau, K., Cronin, S.J. and Lube, G., 2014. Effects of volatile behaviour on dome collapse and resultant pyroclastic surge dynamics: Guning Merapi 2010 eruption. In: G.F. Zellmer, M. Edmonds and S.M. Straub (Editors), The Role of Volatiles in the Genesis, Evolution and Eruption of Arc Magmas. The Geological Society of London, Special Publications, London.

Guéguen, Y. and Palciauskas, V., 1994. Introduction to the Physics of Rocks. Princeton University Press, ISBN: 9780691034522.

Hammer, J.E., Cashman, K.V. and Voight, B., 2000. Magmatic processes revealed by textural and compositional trends in Merapi dome lavas. Journal of Volcanology and Geothermal Research, 100(1-4): 165-192.

Heaney, P.J., 1994. Structure and chemistry of the low-pressure silica polymorphs. Silica: Physical Behavior, Geochemistry and Materials Applications, 29: 1-40.

Heap, M.J., Farquharson, J., Wadsworth, F.B., Kolzenburg, S. and Russell, J.K., 2015. Timescales for permeability reduction and strength recovery in densifying magma. Earth and Planetary Science Letters, 429: 223-233.

Heap, M.J. and Kennedy, B., 2016. Scale-dependent permeability of fractured andesite. In review.

Heap, M.J., Kolzenburg, S., Russell, J.K., Campbell, M.E., Welles, J., Farquharson, J.I. and Ryan, A., 2014a. Conditions and timescales for welding block-and-ash flow deposits. Journal of Volcanology and Geothermal Research, 289: 202-209.

Heap, M.J., Lavallée, Y., Petrakova, L., Baud, P., Reuschlé, T., Varley, N.R. and Dingwell, D.B., 2014b. Microstructural controls on the physical and mechanical properties of edificeforming andesites at Volcán de Colima, Mexico. Journal of Geophysical Research Solid Earth, 119.

Hicks, P.D., Matthews, A.J. and Cooker, M.J., 2009. Thermal structure of a gas-permeable lava dome and timescale separation in its response to perturbation. Journal of Geophysical Research-Solid Earth, 114.

Horwell, C.J., Williamson, B.J., Llewellin, E.W., Damby, D.E. and Le Blond, J.S., 2013. The nature and formation of cristobalite at the Soufrière Hills volcano, Montserrat: implications for the petrology and stability of silicic lava domes. Bulletin of Volcanology, 75(696).

Iguchi, M., Yakiwara, H., Tameguri, T., Hendrasto, M. and Hirabayashi, J.-i., 2008. Mechanism of explosive eruption revealed by geophysical observations at the Sakurajima, Suwanosejima and Semeru volcanoes. Journal of Volcanology and Geothermal Research, 178(1): $1-9$.

Innocenti, S., del Marmol, M.-A., Voight, B., Andreastuti, S. and Furman, T., 2013. Textural and mineral chemistry constraints on evolution of Merapi Volcano, Indonesia. Journal of Volcanology and Geothermal Research, 261: 20-37.

Jaupart, C., 1998. Gas loss from magmas through conduit walls during eruption. In: J.S. Gilbert and R.S.J. Sparks (Editors), The Physics of Explosive Volcanic Eruptions. Geological Society, London, pp. 73-90.

Johnson, J.B., Lees, J.M., Gerst, A., Sahagian, D. and Varley, N., 2008. Long-period earthquakes and co-eruptive dome inflation seen with particle image velocimetry. Nature, 456(7220): 377-381.

Jouniaux, L., Bernard, M.-L., Zamora, M. and Pozzi, J.P., 2000. Streaming potential in volcanic rocks from Mount Pelée. Journal of Geophysical Research, 105(B4): 8391-8401. 
Jousset, P., Budi-Santoso, A., Jolly, A.D., Boichu, M., Surono, Dwiyono, S., Sumatri, S., Hidayati, S. and Thierry, P., 2013a. Signs of magma ascent in LP and VLP seismic events and link to degassing: An example from the 2010 explosive eruption at Merapi volcano, Indonesia. Journal of Volcanology and Geothermal Research, 261: 171-192.

Jousset, P., Pallister, J. and Surono, 2013b. The 2010 eruption of Merapi volcano. Journal of Volcanology and Geothermal Research, 261: 1-6.

Kendrick, J.E., Lavallée, Y., Hess, K.U., Heap, M.J., Gaunt, H.E., Meredith, P.G. and Dingwell, D.B., 2013. Tracking the permeable porous network during strain-dependent magmatic flow. Journal of Volcanology and Geothermal Research, 260: 117-126.

Kennedy, B.M., Wadsworth, F.B., Vasseur, J., Schipper, C.I., Jellinek, A.M., von Aulock, F.W., Hess, K.-U., Russell, J.K., Lavallee, Y., Nichols, A.R.L. and Dingwell, D.B., 2016. Surface tension driven processes densify and retain permeability in magma and lava. Earth and Planetary Science Letters, 433: 116-124.

Klinkenberg, L.J., 1941. The permeability of porous media to liquids and gases. Drilling and production practice: $200-213$.

Klug, C. and Cashman, K.V., 1996. Permeability development in vesiculating magmas: implcations for fragmentation. Bulletin of Volcanology, 58: 87-100.

Kolzenburg, S., Heap, M.J., Lavallée, Y., Russell, J.K., Meredith, P.G. and Dingwell, D.B., 2012. The strength and permeability of tuffisite-bearing andesite in volcanic conduits. Solid Earth Discuss, 4(1): 459-473.

Komorowski, J.-C., Hoblitt, R.P. and Sheridan, M.F., 1997. Silicification and brecciation microtextures of the Mt. St. Helens' 1980 cryptodome-country rock interface: implications for hydrothermal fluid processes, precursory seismicity, and eruptive style, International Association of Volcanology and Chemistry of Earth's Interior, Puerto Vallarta, Mexico, pp. 76.

Komorowski, J.-C., Jenkins, S., Baxter, P.J., Picquout, A., Lavigne, F., Charbonnier, S., Gertisser, R., Preece, K., Cholik, N., Budi-Santoso, A. and Surono, 2013. Paroxysmal dome explosion during the Merapi 2010 eruption: Processes and facies relationships of associated high-energy pyroclastic density currents. Journal of Volcanology and Geothermal Research.

Komorowski, J.-C., Legendre, Y., Christopher, T., Bernstein, L., Stewart, R., Joseph, E., Fournier, N., Chardot, L., Finizola, A., Wadge, G., Syers, R., Williams, C.A. and Bass, V., 2010. Insights into processes and deposits of hazardous vulcanian explosions at Soufrière Hills Volcano during 2008 and 2009 (Montserrat, West Indies). Geophysical Research Letters, 37(L00E19).

Kozeny, J., 1927. Ueber kapillare Leitung der Wasser in Boden, Sitzungsber. Akad. Wiss., Wien, pp. 271-306.

Lavallée, Y., Benson, P.M., Heap, M.J., Hess, K.U., Flaws, A., Schillinger, B., Meredith, P.G. and Dingwell, D.B., 2013. Reconstructing magma failure and the degassing network of dome-building eruptions. Geology, 41(4): 515-518.

Lavallée, Y., Varley, N.R., Alatorre-Ibargueengoitia, M.A., Hess, K.U., Kueppers, U., Mueller, S., Richard, D., Scheu, B., Spieler, O. and Dingwell, D.B., 2012. Magmatic architecture of dome-building eruptions at Volcan de Colima, Mexico. Bulletin of Volcanology, 74(1): 249-260.

Main, I.G., Leonard, T., Papasouliotis, O., Hattion, C.G. and Meredith, P.G., 1999. One slope or two? Detecting statistically significant breaks of slope in geophysical data,with application to fracture scaling relationships. Geophysical Research Letters, 26(18): 28012804.

Martel, C., 2012. Eruption dynamics inferred from microlite crystallization experiments: Application to Plinian and dome-formning eruptions of Mt. Pelée (Martinique, Lesser Antilles). Journal of Petrology, 53(4): 699-725. 
Martel, C. and Iacono-Marziano, G., 2015. Timescales of bubble coalescence, outgassing, and foam collapse in decompressed rhyolitic melts. Earth and Planetary Science Letters, 412: 173-185.

Melnik, O., Barmin, A.A. and Sparks, R.S.J., 2005. Dynamics of magma flow inside volcanic conduits with bubble overpressure buildup and gas loss through permeable magma. Journal of Volcanology and Geothermal Research, 143(1-3): 53-68.

Mueller, S., Melnik, O., Spieler, O., Scheu, B. and Dingwell, D.B., 2005. Permeability and degassing of dome lavas undergoing rapid decompression: An experimental determination. Bulletin of Volcanology, 67: 526-538.

Mueller, S., Scheu, B., Spieler, O. and Dingwell, D.B., 2008. Permeability control on magma fragmentation. Geology, 36: 399-402.

Okumura, S. and Sasaki, O., 2014. Permeability reduction of fractured rhyolite in volcanic conduits and its control on eruption cyclicity. Geology, 42(10): 843-846.

Pallister, J.S., Schneider, D.J., Griswold, J.P., Keeler, R.H., Burton, W.C., Noyles, C., Newhall, C.G. and Ratdomopurbo, A., 2013. Merapi 2010 eruption-Chronology and extrusion rates monitored with satellite radar and used in eruption forecasting. Journal of Volcanology and Geothermal Research, 261: 144-152.

Pistone, M., Arzilli, F., Bobson, K.J., Cordonnier, B., Reusser, E., Ulmer, P., Marone, F., Whittington, A.G., Mancini, L., Fife, J.L. and Blundy, J.D., 2015. Gas-driven filter pressing in magmas: Insights into in-situ melt segregation from crystal mushes. Geology.

Preece, K., Barclay, J., Gertisser, R. and Herd, R.A., 2013. Textural and micro-petrological variations in the eruptive products of the 2006 dome-forming eruption of Merapi volcano, Indonesia: Implications for sub-surface processes. Journal of Volcanology and Geothermal Research, 261: 98-120.

Preece, K., Gertisser, R., Barclay, J., Berlo, K., Herd, R.A. and Facility, E.I.M., 2014. Pre- and syn-eruptive degassing and crystallisation processes of the 2010 and 2006 eruptions of Merapi volcano, Indonesia. Contributions to Mineralogy and Petrology, 168: 1061.

Ratdomopurbo, A., Beauducel, F., Subandriyo, J., Nandaka, I., Newhall, C.G., Suharna, Sayudi, D.S., Suparwaka, H. and Sunarta, 2013. Overview of the 2006 eruption of Mt. Merapi. Journal of Volcanology and Geothermal Research, 261: 87-97.

Rust, A.C. and Cashman, K.V., 2004. Permeability of vesicular silicic magma: inertial and hysteresis effects. Earth and Planetary Science Letters, 228: 93-107.

Rust, A.C., Cashman, K.V. and Wallace, P.J., 2004. Magma degassing buffered by vapor flow through brecciated conduit margins. Geology, 32(4): 349-352.

Saar, M.O. and Manga, M., 1999. Permeability-porosity relationship in vesicular basalts. Geophysical Research Letters, 26: 111-114.

Schipper, C.I., Castro, J.M., Tuffen, H., Wadsworth, F.B., Chappell, D., Pantoja, A.E., Simpson, M.P. and Le Ru, E.C., 2015. Cristobalite in the 2011-2012 Cordon Caulle eruption (Chile). Bulletin of Volcanology, 77(5).

Siebert, L., 1984. Large volcanic debris avalanches: Characteristics of source areas, deposits, and associated eruptions. Journal of Volcanology and Geothermal Research, 22: 163-197.

Siswowidjoyo, S., Suryo, I. and Yokoyama, I., 1995. Magma eruption rates of Merapi Volcano, Central Java, Indonesia during one century (1890-1992). Bulletin of Volcanology, 57(2): 111-116.

Sparks, R.S.J., 1978. The dynamics of bubble formation and growth in magmas: A review and analysis. Journal of Volcanology and Geothermal Research, 3: 1-37.

Sparks, R.S.J., 1997. Causes and consequences of pressurisation in lava dome eruptions. Earth and Planetary Science Letters, 150(3-4): 177-189.

Surono, M., Jousset, P., Pallister, J., Boichu, M., Buongiorno, M.F., Budisantoso, A., Costa, F., Andreastuti, S., Prata, F., Schneider, D., Clarisse, L., Humaida, H., Sumatri, S., Bignam, C., Griswold, J., Carn, S., Oppenheimer, C. and Lavigne, F., 2012. The 2010 explosive 
eruption of Java's Merapi volcano - a '100-year' event. Journal of Volcanology and Geothermal Research(241-242): 121-135.

Swanson, S.E., Naney, M.T., Westrich, H.R. and Eichelberger, J.C., 1989. Crystallization history of Obsidian Dome, Inyo Domes, California. Bulletin of Volcanology, 51: 161-176.

Tait, S., Jaupart, C. and Vergniolle, S., 1989. Pressure, gas content and eruption periodicity of a shallow, crystallising magma chamber. Earth and Planetary Science Letters, 92: 107-123.

Underwood, E.E., 1970. Quantitative stereology. Addison Wesley, Reading.

Varley, N.R., Arambula-Mendoza, R., Reyes-Davila, G., Stevenson, J. and Harwood, R., 2010. Long-period seismicity during magma movement at Volcan de Colima. Bulletin of Volcanology, 72(9): 1093-1107.

Varley, N.R. and Komorowski, J.-C., 2015. Volcán de Colima - Managing the Threat. SpringerVerlag Berlin Heidelberg, 300 pp.

Vasseur, J., Wadsworth, F.B., Lavallee, Y., Hess, K.-U. and Dingwell, D.B., 2013. Volcanic sintering: Timescales of viscous densification and strength recovery. Geophysical Research Letters, 40(21): 5658-5664.

Vinciguerra, S., Trovato, C., Meredith, P.G. and Benson, P.M., 2005. Relating seismic velocities, thermal cracking and permeability in Mt. Etna and Iceland basalts. International Journal of Rock Mechanics and Mining Sciences, 42(7-8): 900-910.

Voight, B., Constantine, E.K., Siswowidjoyo, S. and Torley, R., 2000. Historical eruptions of Merapi Volcano, Central Java, Indonesia, 1768-1998. Journal of Volcanology and Geothermal Research, 100: 69-138.

Whitaker, S., 1996. The Forchheimer equation: A theoretical develpment. Transport in Porous Media, 25: 27-61.

Williamson, B.J., Di Muro, A., Horwell, C.J., Spieler, O. and Llewellin, E.W., 2010. Injection of vesicular magma into an andesitic dome at the effusive-explosive transition. Earth and Planetary Science Letters, 295(1-2): 83-90.

Wong, T.F., 1985. Geometric probability approach to the characterization and analysis of microcracking in rocks. Mechanics of Materials, 4(3-4): 261-276.

Woods, A.W. and Koyaguchi, T., 1994. Transitions between explosive and effusive eruptions of silicic magmas. Nature, 370(6491): 641-644.

Wright, H.M.N., Cashman, K.V., Gottesfeld, E.H. and Roberts, J.J., 2009. Pore structure of volcanic clasts: Measurements of permeability and electrical conductivity. Earth and Planetary Science Letters, 280: 93-104.

Wright, H.M.N., Lesti, C., Cas, R.A.F., Porreca, M., Viramonte, J.G. and Giordano, G., 2011. Columnar jointing in vapour-phase-altered, non-welded Cerro Galán Ignimbrite, Paycuqui, Argentina. Bulletin of Volcanology, 73: 1567-1582.

Wright, H.M.N., Roberts, J.J. and Cashman, K.V., 2006. Permeability of anisotropic tube pumice: Model calculations and measurements. Geophysical Research Letters, 33.

Wu, X.Y., Baud, P. and Wong, T.-F., 2000. Micromechanics of compressive failure and spatial evolution of anisotropic damage in Darley Dale sandstone. International Journal of Rock Mechanics and Mining Sciences, 37: 143-160.

Yokoo, A., Tameguri, T. and Iguchi, M., 2009. Swelling of a lava plug associated with a Vulcanian eruption at Sakurajima Volcano, Japan, as revealed by infrasound record: case study of the eruption on January 2, 2007. Bulletin of Volcanology, 71(6): 619-630.

\section{Figure captions}

Figure 1 A Sample locations for rocks sampled after the 2006, 2010, and 2013 eruptions at Merapi, Java, Indonesia. All 2006 and 2010 samples were collected at locations 1303, 1323, 
1333, and 1351 (in the Gendol River valley) and location 1323 (Bakalan Village) in August 2013, see Table 1. 2013 samples were collected at SV10 and SV12 in November 2013, after a small ash-venting event. Top right inset image is a map of Indonesia; Merapi's location on the island of Java is indicated by the red triangle; scale bar $1500 \mathrm{~km}$. Bottom left inset image is of the western flank of the volcano, as indicated by the dotted white lines and arrow; taken August 2013. Map images taken from Google Earth. B Dome map following the 1997 eruption (modified from Voight et al. (2000), Charbonnier and Gertisser (2008), and Innocenti et al. (2013)). The dome rocks used in this study came from domes shaded in purple and were sampled by Abdurachman (1998) in 1997. Exact sampling locations are not known.

Figure 2 Merapi basaltic andesite microstructure. SEM backscattered electron images show the sample groundmass and phenocrysts for Types 1, 2, and 3 clasts; scale bars $200 \mu \mathrm{m}$. Inset photographs are of the cores on which permeability measurements were made; scale bar $20 \mathrm{~mm}$. A Type 1 . Sample $10 \_7 ; \varphi_{\text {gas }}=53.3$ vol. $\%$. Type 1 samples are light grey and visibly vesicular in hand sample. Bubble sizes range from several microns to millimetres. B (sample 10_20; $\varphi_{\text {gas }}=$ 28.0 vol. \%) and C (sample 10_12; $\varphi_{\text {gas }}=13.0$ vol.\%) Type 2 . Samples are consistently dark grey to black in hand sample. The groundmass is partially vitric. Vesicles are rounded; microcracks are continuous between the groundmass and phenocrysts. White arrows highlight thoroughgoing microcracks. D (sample 10_25; $\varphi_{\text {gas }}=12.1$ vol.\%.) and E (sample 10_22; $\varphi_{\text {gas }}=7.4$ vol.\%.) Type 3. Samples are medium to light grey in hand sample. Groundmass is partially vitric to devitrified. Phenocrysts are heavily microcracked, whereas few microcracks continue into the groundmass. Vesicles are rare, but present. Both diktytaxitic textures and cristobalite are prevalent. White arrows identify region with diktytaxitic textures. In all images: cpx - clinopyroxene, ox - oxide minerals, $\mathrm{pl}$ - plagioclase, $\mathrm{c}$ - cristobalite.

Figure 3 Bulk geochemical data for Merapi basalts and basaltic andesites. A. By eruption date. Data for the 1930 to 1997 eruptions from Abdurachman (1998). Data for the 2006 and 2010 eruptions from Preece et al. (2013). Additional data for the 2010 and 2013 eruptions are from (Erdmann et al., 2016) and this study. B. By lithological type: Type 2 and Type 3.

Figure 4 SEM images of microlite textures in Types 1, 2, and 3 basaltic andesites; scale bars 50 $\mu \mathrm{m}$. A Type 1; sample 10_7. Plagioclase microlites are tabular in shape, with low aspect ratios. B Type 2; sample 10_20. Needle-like plagioclase microlites (light grey) are abundant in the vitric groundmass. C and D Type 3. C Sample 06_2. Microlites are euhedral and tabular. Feather 
textures (Horwell et al., 2013) suggest devitrification of the groundmass to cristobalite; indicated by the white arrow. Some microlites show rounded edges, suggesting re-melting; indicated by the white circle. D Sample 13_3. Microlites are needle-like; groundmass is glass-bereft and microlite supported, giving rise to diktytaxitic textures. Diktytaxitic features are common in all Type 3 samples, though prevalence varies from sample to sample.

Figure 5 A Permeability-connected porosity data. Black, open circles are Type 1 basaltic andesites; black, filled circles are Type 2 basaltic andesites; and grey, filled circles with black outlines are Type 3 basaltic andesites. Lines of best fit are given for each rock type, see text for details. Relative error on connected porosity and permeability data is $1 \%$. B Permeability-specific surface area data for six selected 2010 samples (see text for details) and all the historical dome samples. Circles denote samples for which both permeability and specific surface area were independently measured. Relative error on measured connected porosity and permeability data is $1 \%$. Diamonds denote samples for which only specific surface area was measured and permeability was subsequently modelled using the Kozeny-Carman relationship (see text for details). C Permeability-connected porosity for all Merapi samples. Circles denote samples for which both permeability and porosity were measured. Diamonds denote samples for which permeability was modelled using the Kozeny-Carman relationship. Red symbols denote samples in which diktytaxitic textures and cristobalite are confirmed by SEM.

Figure 6 Cristobalite and diktytaxitic textures. c - cristobalite. A and B SEM images of Merapi samples. Diktytaxitic textures are always associated with cristobalite and occur regardless of microlite morphology (tabular or needle-like). A Sample 10_24. Pervasive diktytaxitic textures associated with fish-scale, vesicle-filling cristobalite. Plagioclase microlites are tabular. Scale bar $200 \mu \mathrm{m}$. B Sample 13_2. Diktytaxitic textures associated with cristobalite. Microlites are needlelike, as in the 2010 Type 2 samples. Cristobalite displays fish-scale microcracking. Scale bar 50 $\mu \mathrm{m}$. C and D SEM images of experiment D6 from Martel (2012), showing a spatial relationship between diktytaxitic textures and cristobalite presence. $\mathbf{C}$ Cristobalite is vesicle filling. Diktytaxitic textures are dominant. Plagioclase microlites are needle-like. Scale bar $200 \mu \mathrm{m}$. D Cristobalite anchored to the sample by a vitric root (black arrow). Scale bar $50 \mu \mathrm{m}$.

Figure 7 Cristobalite, diktytaxitic textures, and permeability. A Cristobalite content (area\%) vs. diktytaxitic porosity (area\%). Cristobalite content and diktytaxitic porosity show a rough positive 
correlation. B Permeability vs. connected porosity of all samples confirmed to have diktytaxitic textures and cristobalite. Solid, black triangles denote samples for which both permeability and connected gas porosity were independently measured; relative error on connected porosity and permeability data is $1 \%$. Grey triangles with black outlines denote samples for which connected water porosity was measured and permeability was modelled using the Kozeny-Carman relationship (see text for details). C Permeability vs. cristobalite content/diktytaxitic porosity. Permeability increases with both cristobalite content and diktytaxitic porosity, see text for more details.

Figure 8 Permeability-connected porosity data of Merapi samples (this study) together with andesites from Volcán de Colima (Mexico) and Montagne Pelée (Martinique). Filled symbols denote data for lava, as identified in the individual studies (equivalent to Type 2 and Type 3 samples in the present study). Open symbols denote all samples identified as pumiceous (equivalent to Type 1 samples in the present study). Yellow samples denote samples for which diktytaxitic textures were confirmed by SEM. The dotted grey line is the line of best fit for all the data. Blue dashed lines denote statistically significant changepoint connected porosities, as determined by piecewise linear regression and confirmed by modified BIC analysis. Changepoint analysis is performed on all data with porosity greater than 5 vol.\%, see text for details. Changepoints are at $\varphi_{c}=10.5$ and $31 \mathrm{vol} . \%$. The data is divided into four microstructural domains. Domain 1 ( $\varphi_{c}<5$ vol. \%): the microstructural control on permeability is unknown. Domain $2\left(6<\varphi_{c}<10.5\right.$ vol.\%): permeability is microcrack- and diktytaxitic-controlled; the solid line is the best-fit power law for this domain. Domain $3\left(10.5<\varphi_{c}<31\right.$ vol.\%): permeability is vesicle- and microcrack-controlled; the solid line is the best-fit power law for this domain. Domain 4 ( $\varphi_{c}>31$ vol.\%): permeability is vesicle-controlled; this domain is dominated by samples with pumiceous textures. Farquharson et al. (2015), Bernard et al. (2007), and Jouniaux et al. (2000) provide gas permeability and connected gas porosities; Heap et al. (2014b), Kendrick et al. (2013), and Kolzenburg et al. (2012) provide water permeability and connected water porosities.

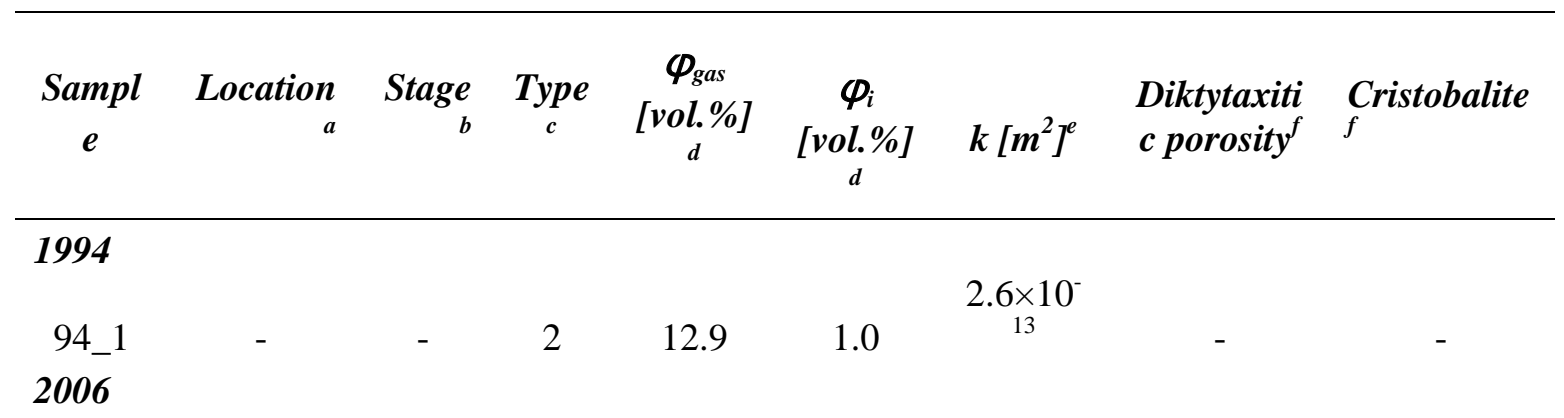




\begin{tabular}{|c|c|c|c|c|c|c|c|c|}
\hline 06_1 & 1333 & - & 2 & 28.7 & 3.0 & $\begin{array}{c}1.8 \times 10^{-} \\
11\end{array}$ & $\mathrm{n}$ & - \\
\hline 06_2 & 1333 & - & 3 & 10.5 & 4.0 & $\underset{14}{2.6 \times 10^{-}}$ & $\mathrm{y}(3.3 \%)$ & $\mathrm{y}(3.3 \%)$ \\
\hline 2010 & & & & & & & & \\
\hline 10_1 & 1333 & 2 & 1 & 38.0 & 4.6 & 14 & $\mathrm{n}$ & $\mathrm{n}$ \\
\hline 10_2 & 1333 & 2 & 1 & 38.9 & 3.9 & 13 & - & - \\
\hline 10_3 & 1333 & 2 & 1 & 39.4 & 4.2 & 12 & $\mathrm{n}$ & $\mathrm{n}$ \\
\hline 10_4 & 1333 & 2 & 1 & 44.3 & 4.6 & & - & - \\
\hline $10 \_5$ & 1333 & 2 & 1 & 46.4 & 5.9 & 13 & - & - \\
\hline 10_6 & 1333 & 2 & 1 & 51.6 & 5.1 & $\begin{array}{c}1.0 \times 10 \\
13\end{array}$ & - & - \\
\hline $10 \_7$ & 1333 & 6 & 1 & 53.3 & 4.8 & $\underset{13}{5.4 \times 10}$ & $\mathrm{n}$ & $\mathrm{n}$ \\
\hline $10 \_8$ & 1333 & 4 & 2 & 10.5 & 3.1 & $\begin{array}{c}1.3 \times 10^{-} \\
14\end{array}$ & - & - \\
\hline 10_9 & 1333 & 4 & 2 & 11.8 & 1.6 & $\begin{array}{c}9.0 \times 10^{-} \\
14\end{array}$ & $\mathrm{n}$ & $\mathrm{n}$ \\
\hline 10_10 & 1333 & 4 & & 12.1 & 2.9 & $\underset{14}{2.1 \times 10^{-}}$ & - & - \\
\hline 10_11 & 1351 & 4 & & 12.5 & 3.1 & $\underset{13}{1.2 \times 10^{-}}$ & $\mathrm{n}$ & $\mathrm{n}$ \\
\hline 10_12 & 1351 & 4 & 2 & 13.0 & 3.1 & $\underset{14}{6.2 \times 10^{-}}$ & $\mathrm{n}$ & $\mathrm{n}$ \\
\hline 10_13 & 1351 & 4 & 2 & 15.8 & 3.5 & $\underset{13}{2.5 \times 10^{-}}$ & - & - \\
\hline 10_14 & 1333 & 4 & 2 & 17.1 & 3.6 & $\underset{13}{4.8 \times 10^{-}}$ & $\mathrm{n}$ & $\mathrm{n}$ \\
\hline 10_15 & 1333 & 4 & 2 & 17.9 & 3.4 & $\underset{13}{9.9 \times 10^{-}}$ & - & - \\
\hline 10_16 & 1333 & 4 & 2 & 21.2 & 3.2 & $\underset{12}{1.6 \times 10^{-}}$ & - & - \\
\hline 10_17 & 1333 & 4 & 2 & 22.8 & 2.9 & $\underset{12}{1.6 \times 10^{-}}$ & - & - \\
\hline 10_18 & 1303 & 4 & 2 & 24.9 & 3.0 & $\underset{12}{4.5 \times 10^{-}}$ & - & - \\
\hline 10_19 & 1323 & 4 & 2 & 26.1 & 3.6 & $\underset{12}{4.6 \times 10^{-}}$ & - & - \\
\hline 10_20 & 1303 & 4 & 2 & 28.0 & 2.9 & $\begin{array}{c}8.9 \times 10^{-} \\
12\end{array}$ & $\mathrm{n}$ & $\mathrm{n}$ \\
\hline 10_21 & 1303 & 4 & 2 & 30.8 & 3.5 & $\underset{11}{1.6 \times 10^{-}}$ & - & - \\
\hline 10_22 & 1333 & 2 & 3 & 7.4 & 3.7 & $\underset{16}{1.6 \times 10^{-}}$ & $\mathrm{y}(3.2 \%)$ & $\mathrm{y}(0.4 \%)$ \\
\hline 10_23 & 1333 & 2 & 3 & 10.8 & 5.4 & 15 & - & - \\
\hline
\end{tabular}




\begin{tabular}{|c|c|c|c|c|c|c|c|c|}
\hline 10_24 & 1333 & 2 & 3 & 11.4 & 6.3 & $\underset{14}{3.6 \times 10^{-}}$ & y $(5.2 \%)$ & у $(3.9 \%)$ \\
\hline $10 \_25$ & 1303 & 4 & 3 & 12.1 & 2.8 & $\underset{15}{4.0 \times 10^{-}}$ & $\mathrm{y}(2.5 \%)$ & $\mathrm{y}(0.6 \%)$ \\
\hline 10_26 & 1303 & 4 & 3 & 13.5 & 2.6 & $\underset{15}{9.9 \times 10^{-}}$ & & $\mathrm{y}$ \\
\hline \multicolumn{9}{|l|}{2013} \\
\hline $13 \_1$ & - & - & 2 & 22.8 & 2.2 & & - & - \\
\hline $13 \_2$ & SV10 & - & 3 & 10.7 & 5.6 & & $\mathrm{y}(8.2 \%)$ & $\mathrm{y}(4.9 \%)$ \\
\hline $13 \_3$ & SV11 & - & 3 & 13.9 & 5.6 & 14 & $\mathrm{y}(2.7 \%)$ & $\mathrm{y}(1.5 \%)$ \\
\hline
\end{tabular}

Table 1 Physical and microstructural properties for rocks in this study.

${ }^{\text {a }}$ See Figure 1A for sample locations.

${ }^{\mathrm{b}}$ Eruption stages for rocks sampled from the 2010 deposits as described in the text (following Komorowski et al. (2013)).

${ }^{\mathrm{c}}$ Rock Type definitions are given in Table 2 and discussed in the text.

${ }^{\mathrm{d}} \varphi_{\text {gas }}$ and $\varphi_{i}$ are connected and isolated gas porosity, respectively; relative error is $1 \%$.

${ }^{\mathrm{e}} k$ is permeability; relative error is $1 \%$.

${ }^{\mathrm{f}}$ Presence (y) or absence (n) of diktytaxitic textures and cristobalite, as observed by SEM (- for no imaging); Percentages in brackets are measurements of either the void space area within diktytaxitic textures or the cristobalite area recalculated on a void-free basis (see text). 
Table 2 Rock type classification for Merapi eruptive products.

\begin{tabular}{|c|c|c|c|}
\hline Rock type classification & Type 1 & Type 2* & Type 3 \\
\hline Field description & $\begin{array}{l}\text { white/grey, } \\
\text { vesicular, crystal- } \\
\text { rich to crystal-poor } \\
\text { (pumiceous) }\end{array}$ & $\begin{array}{l}\text { unaltered, dark grey, } \\
\text { glassy, variably } \\
\text { vesiculated, crystal- } \\
\text { rich to crystal-poor }\end{array}$ & $\begin{array}{l}\text { light grey, weakly } \\
\text { vesicular, crystal- } \\
\text { rich to crystal-poor }\end{array}$ \\
\hline \multicolumn{4}{|l|}{ Microstructure description } \\
\hline Phenocrysts & rarely fractured & rarely fractured & $\begin{array}{l}\text { pervasively } \\
\text { fractured }\end{array}$ \\
\hline Plagioclase microlites & $\begin{array}{l}\text { moderately } \\
\text { prevalent; low } \\
\text { aspect ratio, tab }\end{array}$ & $\begin{array}{l}\text { prevalent; euhedral, } \\
\text { elongated }\end{array}$ & $\begin{array}{l}\text { prevalent; euhedral } \\
\text { to subrounded, } \\
\text { tabular; triple } \\
\text { junction melting } \\
\text { points }\end{array}$ \\
\hline Glass & pristine & pristine & generally devitrified \\
\hline Cristobalite & absent & absent & present \\
\hline Diktytaxitic texture & absent & absent & present \\
\hline Porosity & $\begin{array}{l}\text { high; bimodal } \\
\text { population (very } \\
\text { large and small } \\
\text { vesicles) }\end{array}$ & $\begin{array}{l}\text { high (scoria) to low } \\
\text { (dense clast); } \\
\text { fractured } \\
\text { groundmass; } \\
\text { pervasive vesicles }\end{array}$ & $\begin{array}{l}\text { weakly vesicular; } \\
\text { few groundmass } \\
\text { fractures; } \\
\text { diktytaxitic texture } \\
\text { prevalent }\end{array}$ \\
\hline \multicolumn{4}{|l|}{$\begin{array}{l}\text { Physical property } \\
\text { measurements }\end{array}$} \\
\hline$\varphi_{\text {gas }}[\text { vol\% }]^{a}$ & to 53.3 & 10.5 to 30.8 & 7.4 to 13.5 \\
\hline & $\begin{array}{l}3.9 \text { to } 5.9 \\
9.3 \times 10^{-14} \text { to } 1.6 \times 10^{-}\end{array}$ & $\begin{array}{l}1.0 \text { to } 4.0 \\
1.3 \times 10^{-14} \text { to } 1.8 \times 10^{-}\end{array}$ & $\begin{array}{l}2.6 \text { to } 6.3 \\
1.6 \times 10^{-16} \text { to } 4.2 \times 10^{-}\end{array}$ \\
\hline$k\left[m^{2}\right]^{b}$ & & & \\
\hline$S_{B E T}\left[m^{2} / \mathrm{kg}\right]^{c}$ & 66 & 23 to 67 & 69 to 1961 \\
\hline
\end{tabular}


* equivalent to Types 1 and 2 of Komorowski et al. (2013)

${ }^{\mathrm{a}} \varphi_{\text {gas }}$ and $\varphi_{i}$ are connected and isolated gas porosity, respectively.

${ }^{\mathrm{b}} k$ is permeability.

${ }^{\mathrm{c}} S_{B E T}$ is specific surface area. 


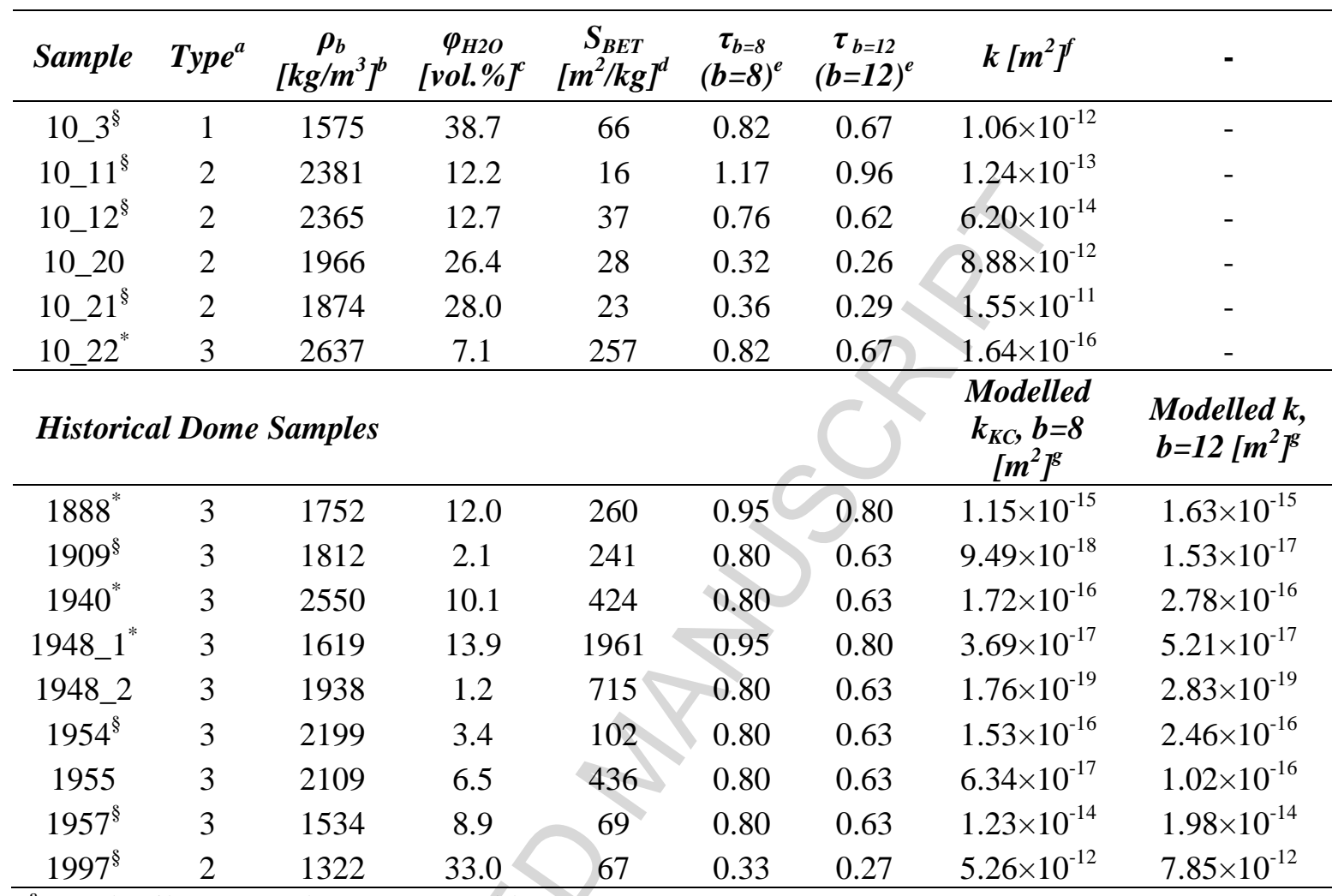

${ }^{\mathrm{a}}$ For details on sample type, see Table 2.

${ }^{\mathrm{b}} \rho_{b}$ is dry bulk density;

${ }^{c} \varphi_{H 2 O}$ is connected water porosity;

${ }^{\mathrm{d}} S_{B E T}$ is specific surface area;

${ }^{\mathrm{e}} \tau_{b=8}$ and $\tau_{b=12}$ are tortuosity determined for $b=8$ and 12 , respectively;

${ }^{\mathrm{f}} k$ is permeability;

${ }^{\mathrm{g}} k_{K C}$ is permeability modelled using the Kozeny-Carman relationship;

* denotes samples bearing diktytaxitic textures and cristobalite, as confirmed by SEM;

$\S$ denotes samples that contain neither diktytaxitic textures nor cristobalite, as confirmed by SEM.

Table 3 Specific surface area and permeability modelled using the Kozeny-Carman relationship. Samples from the 2010 eruptions (prefixed with 10_) are used to constrain sample tortuosity using Eq. 2. These values are assigned to the historical dome samples based on lithological classification and $k_{K C}$ is modelled using the Kozeny-Carman relationship for $b=8$ and 12 (see text for details). Historical dome sample names denote the year of eruption. 


\section{Highlights:}

- We present porosity-permeability data for rocks from Merapi, Indonesia

- Distinct changes in the porosity-permeability trend (connected porosity $=10.5$ and 31 vol.\%) define changes in the dominant microstructure controlling permeability

- Cristobalite formation may not reduce permeability due to the associated diktytaxitic texture

- Low-permeability dome material is found to be present in all historic Merapi domes

- A low-permeability dome did not contribute to the explosivity of the 2010 Merapi eruption 

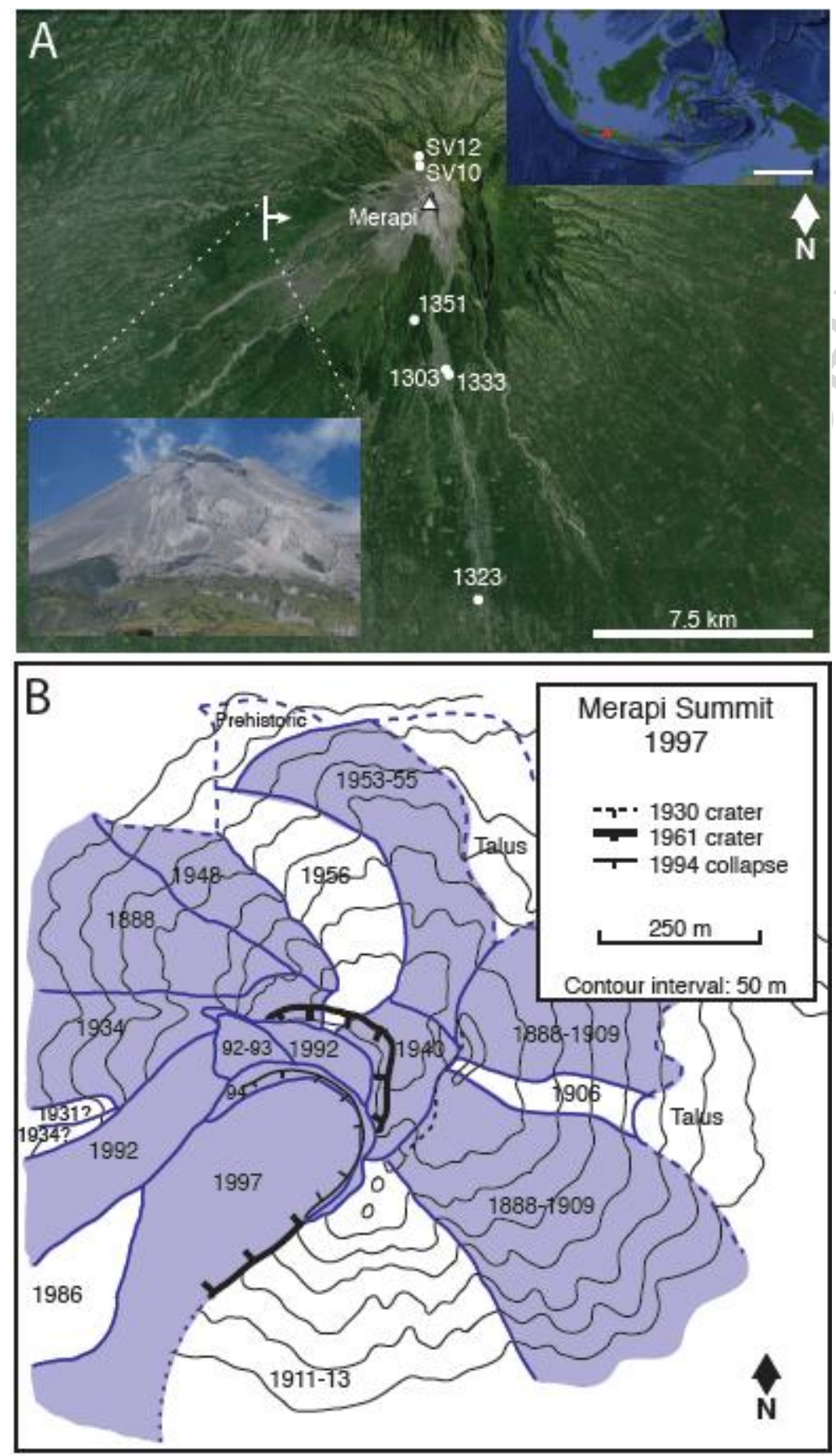

Figure 1 


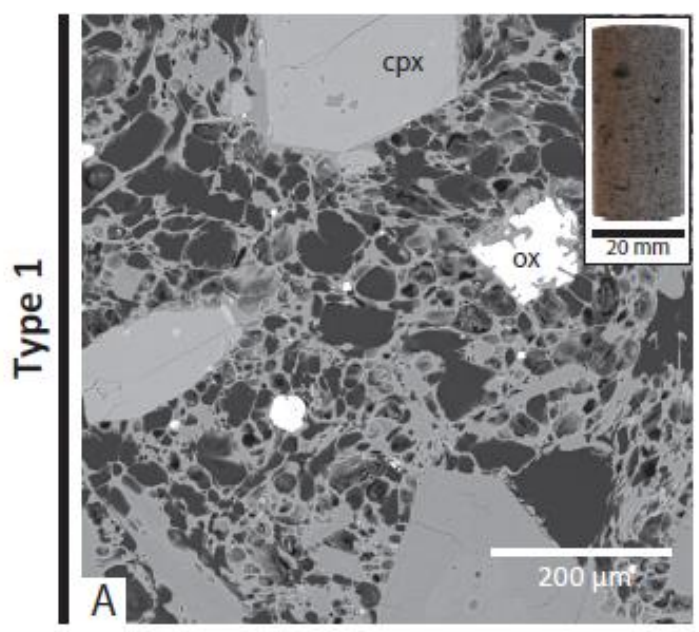

Figure 2
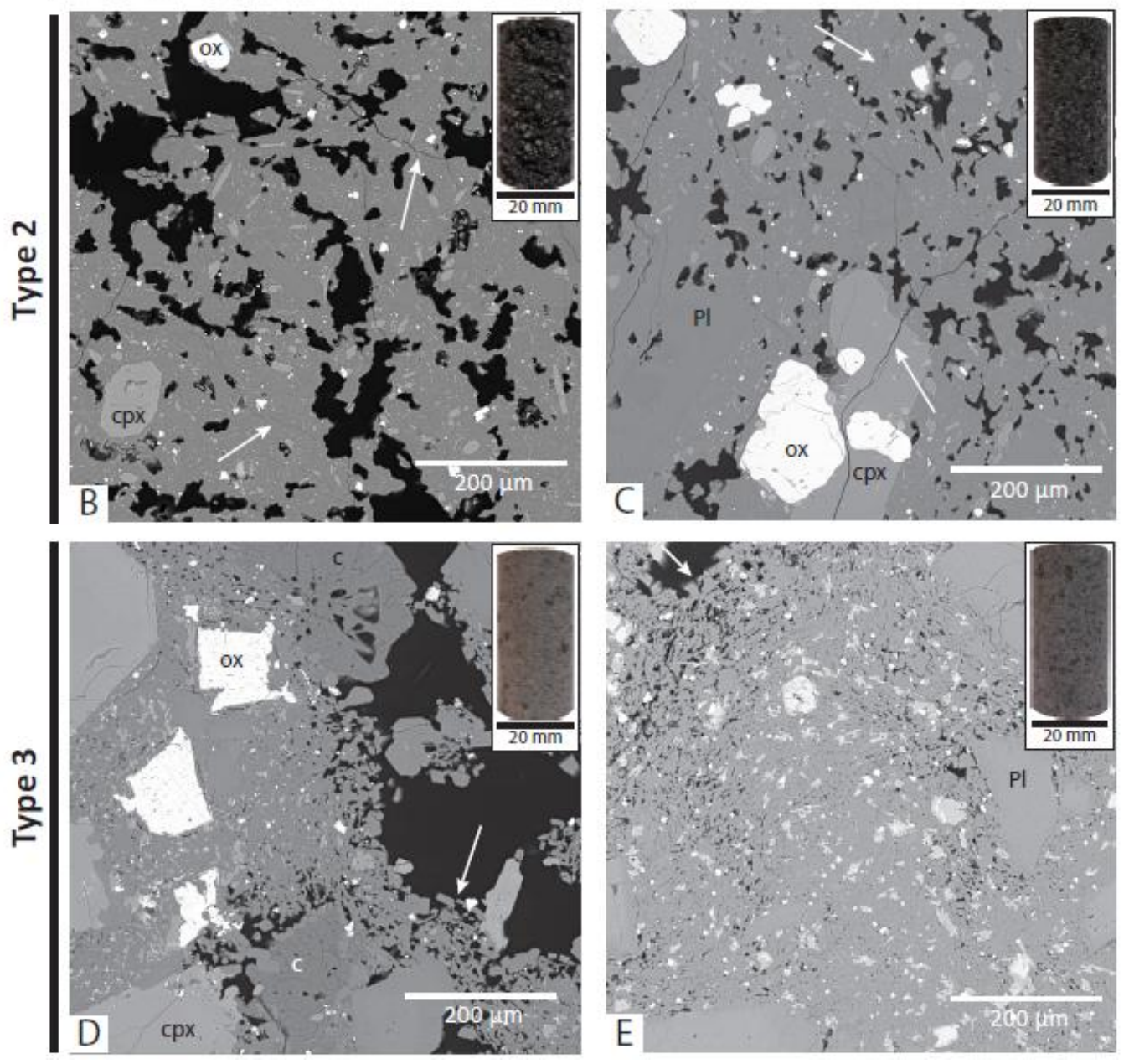

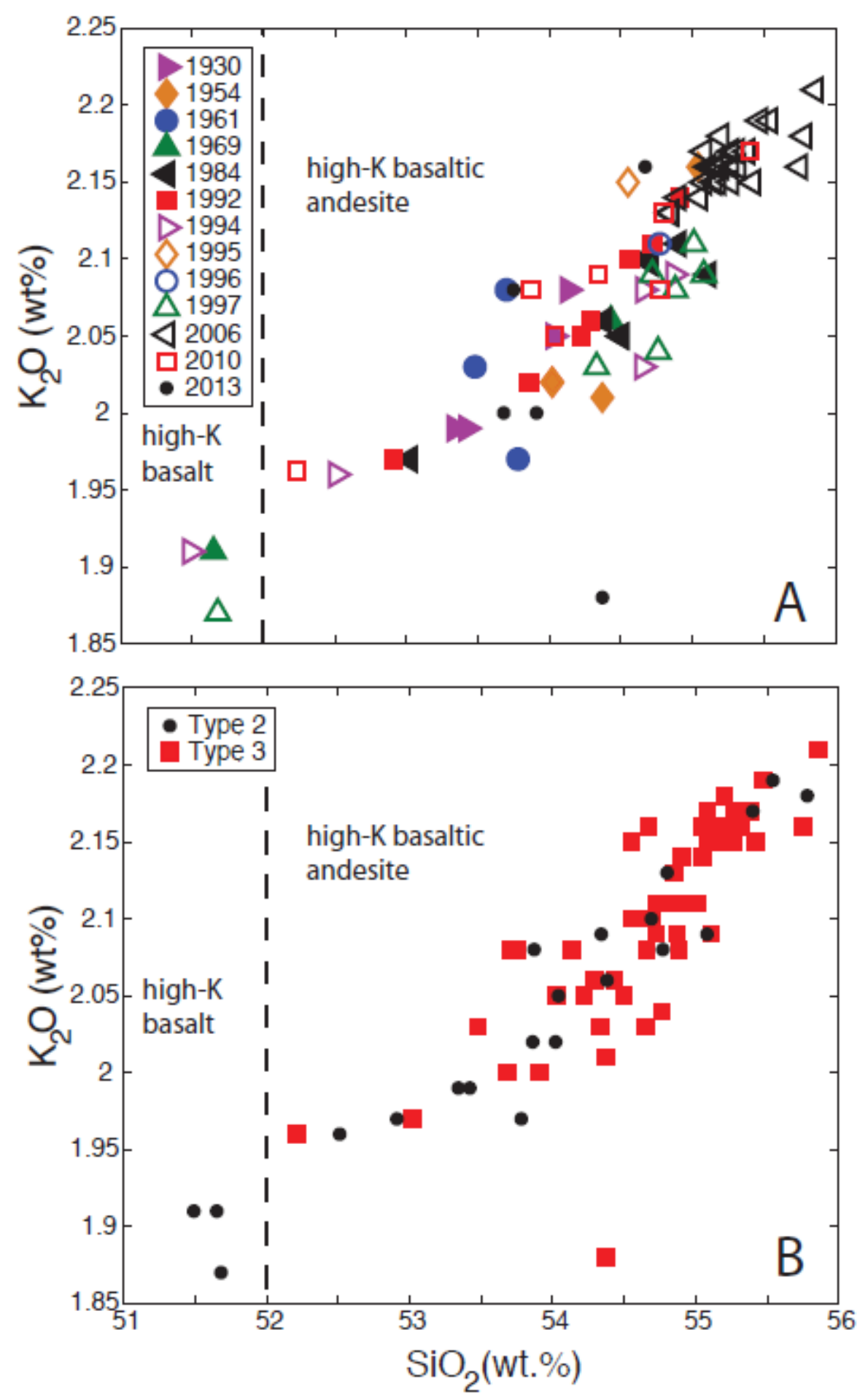

Figure 3 


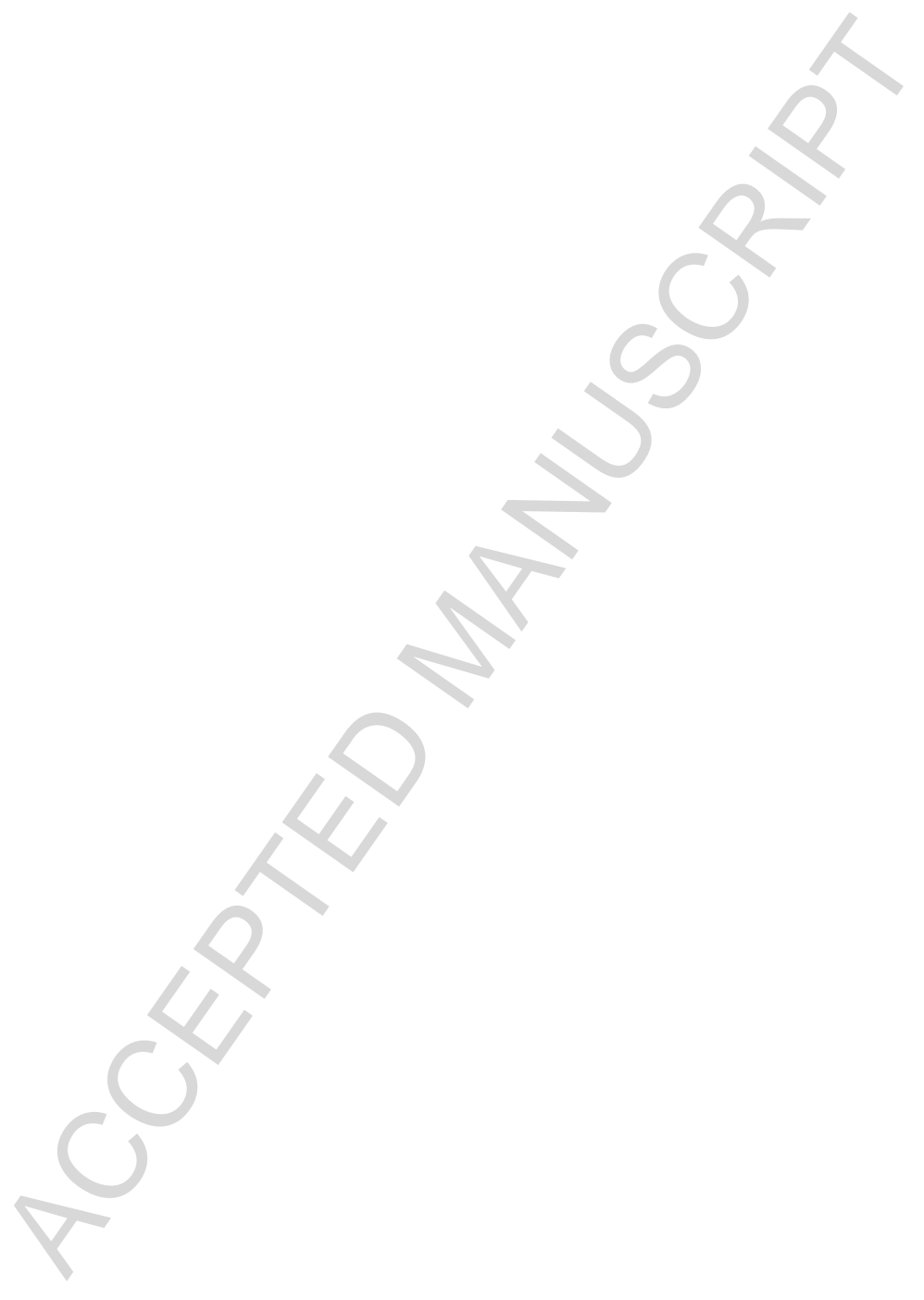



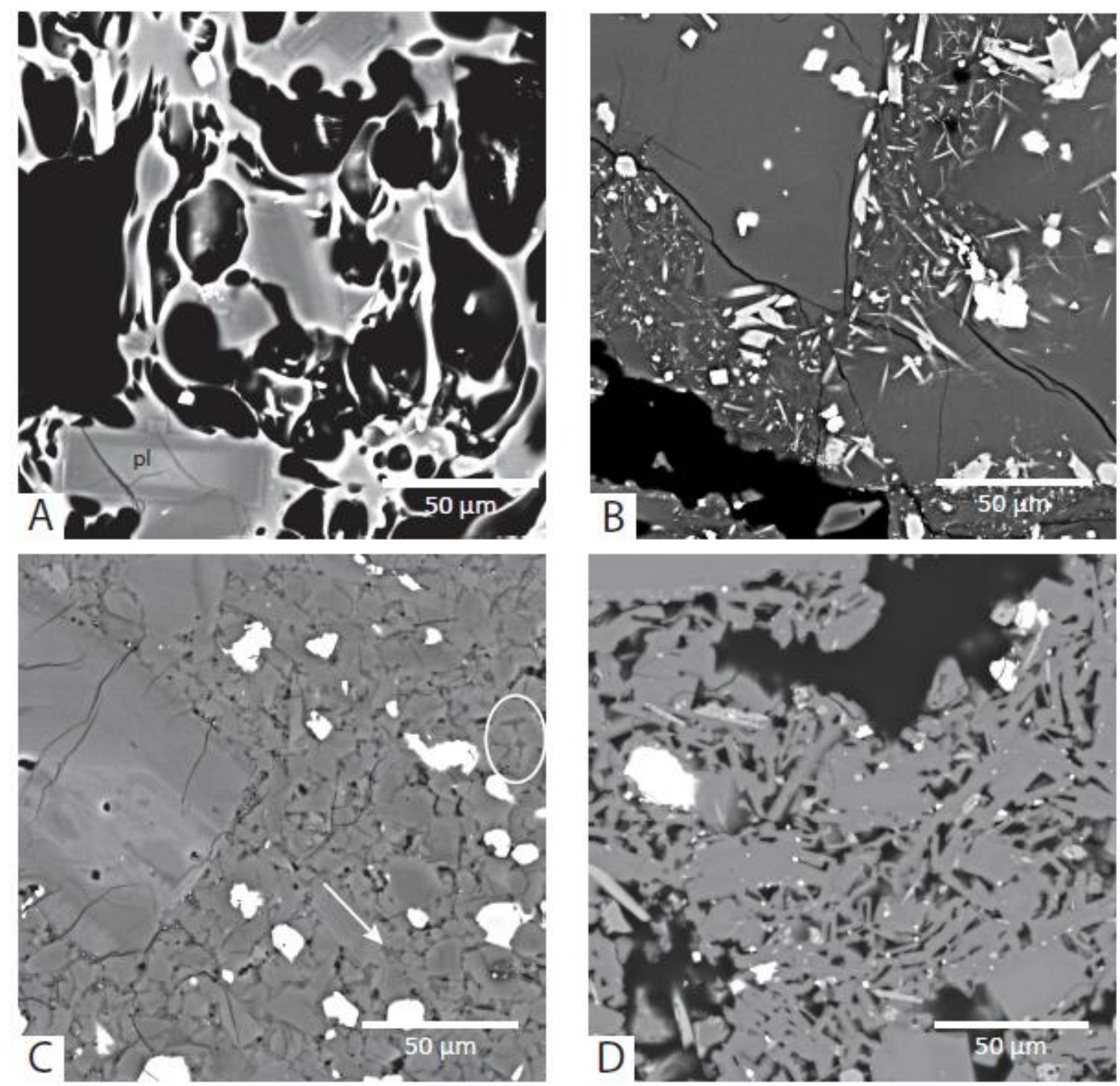

Figure 4 

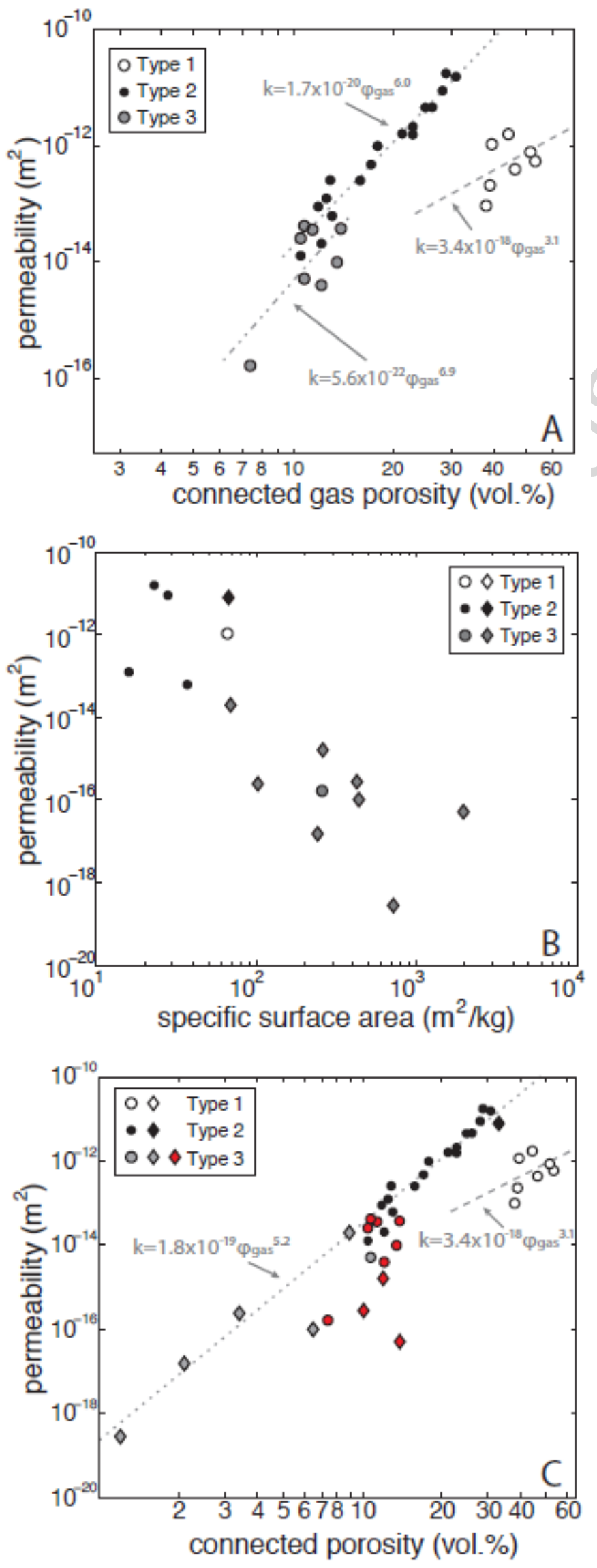

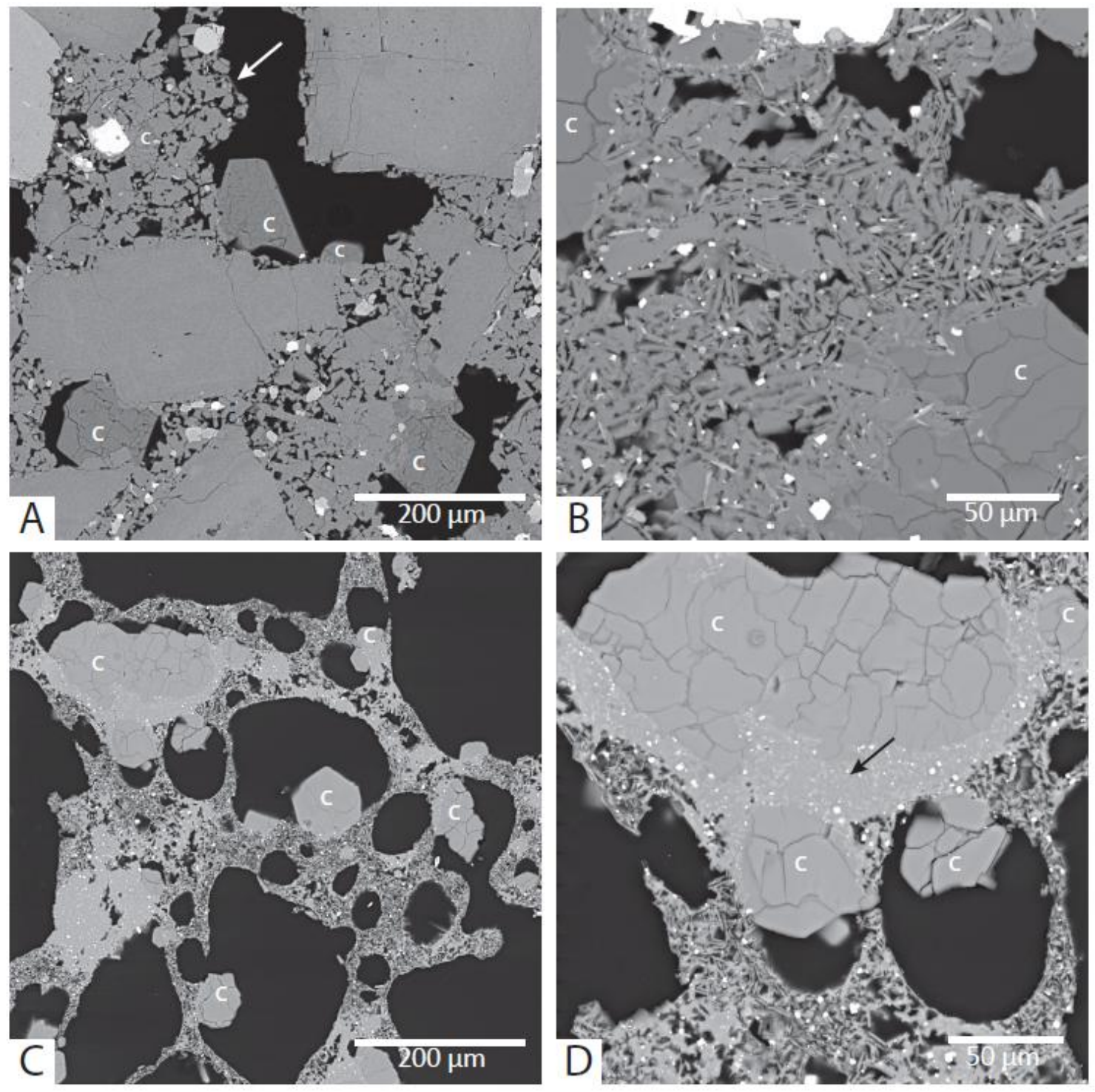

Figure 6 

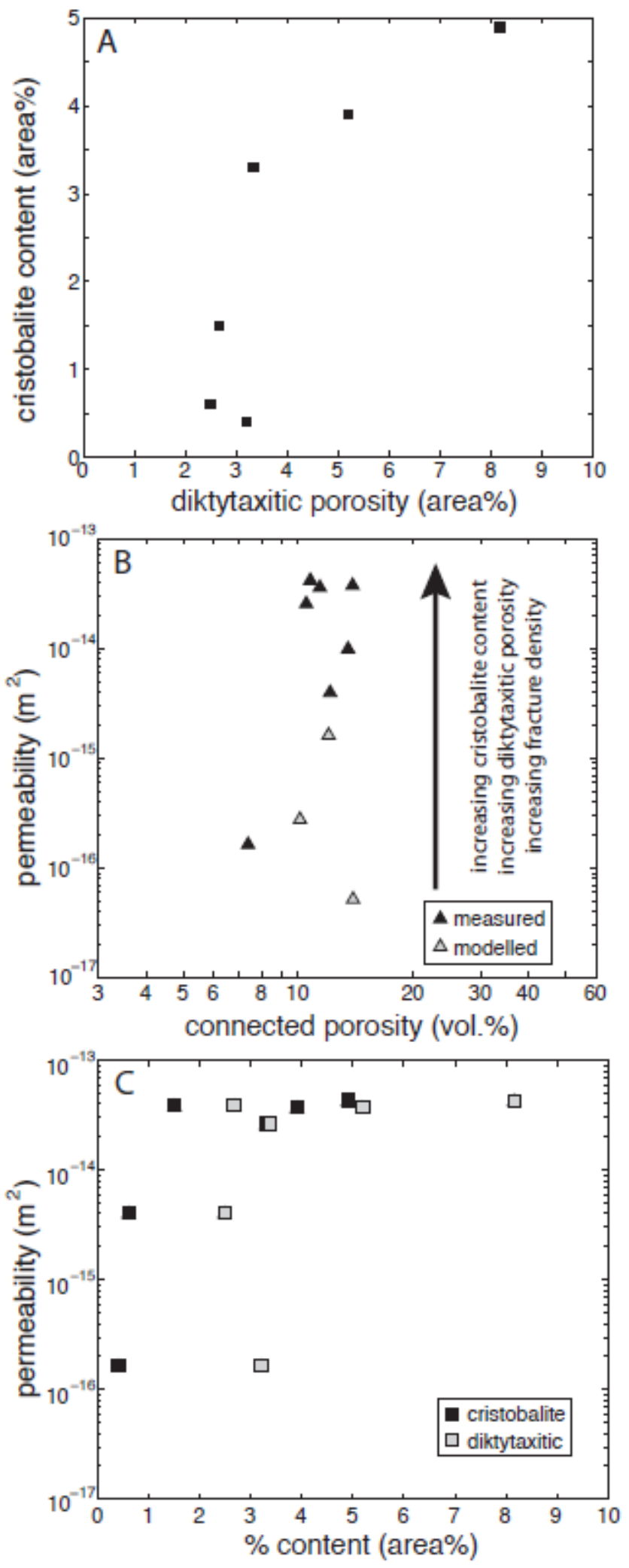

Figure 7 


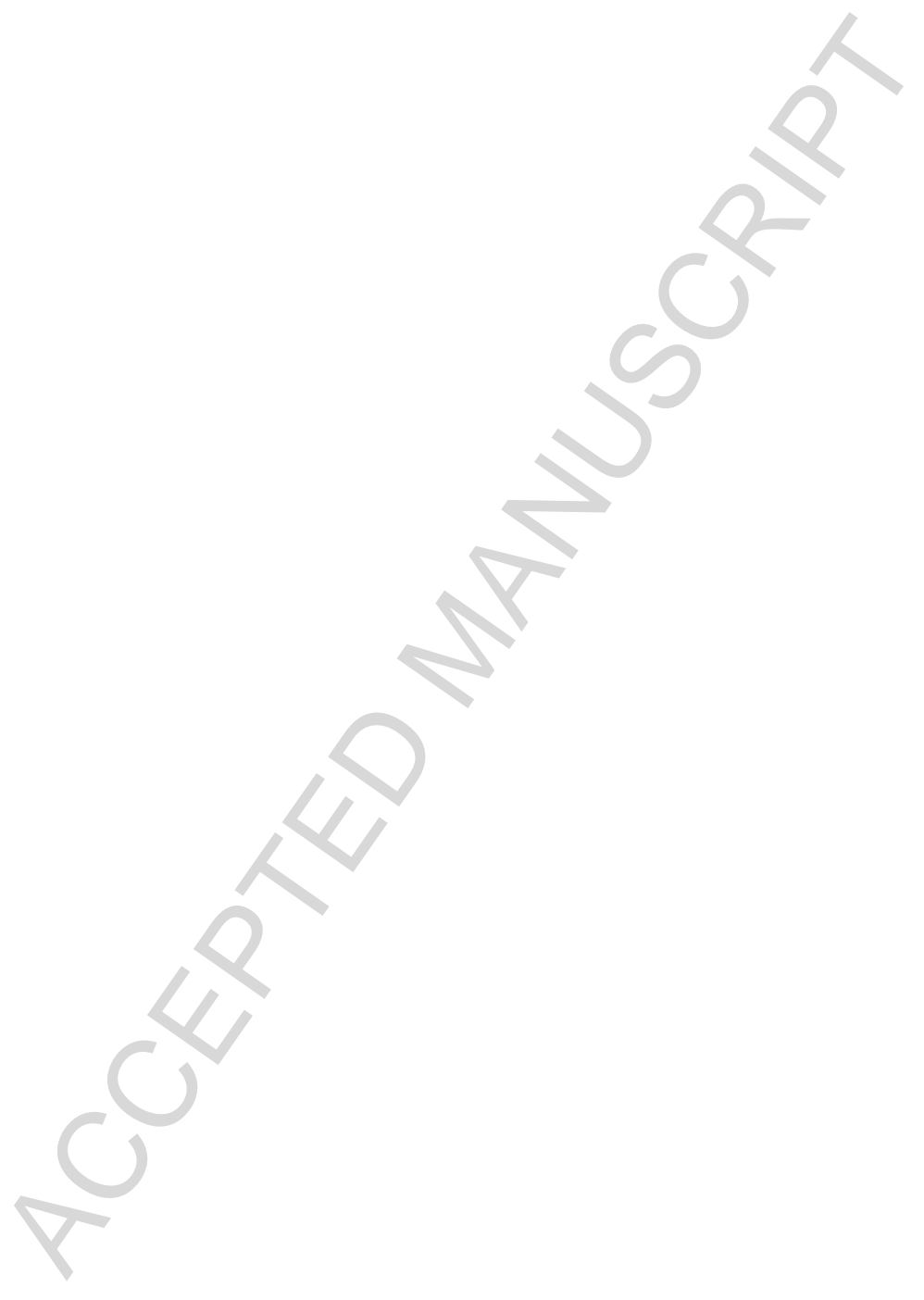




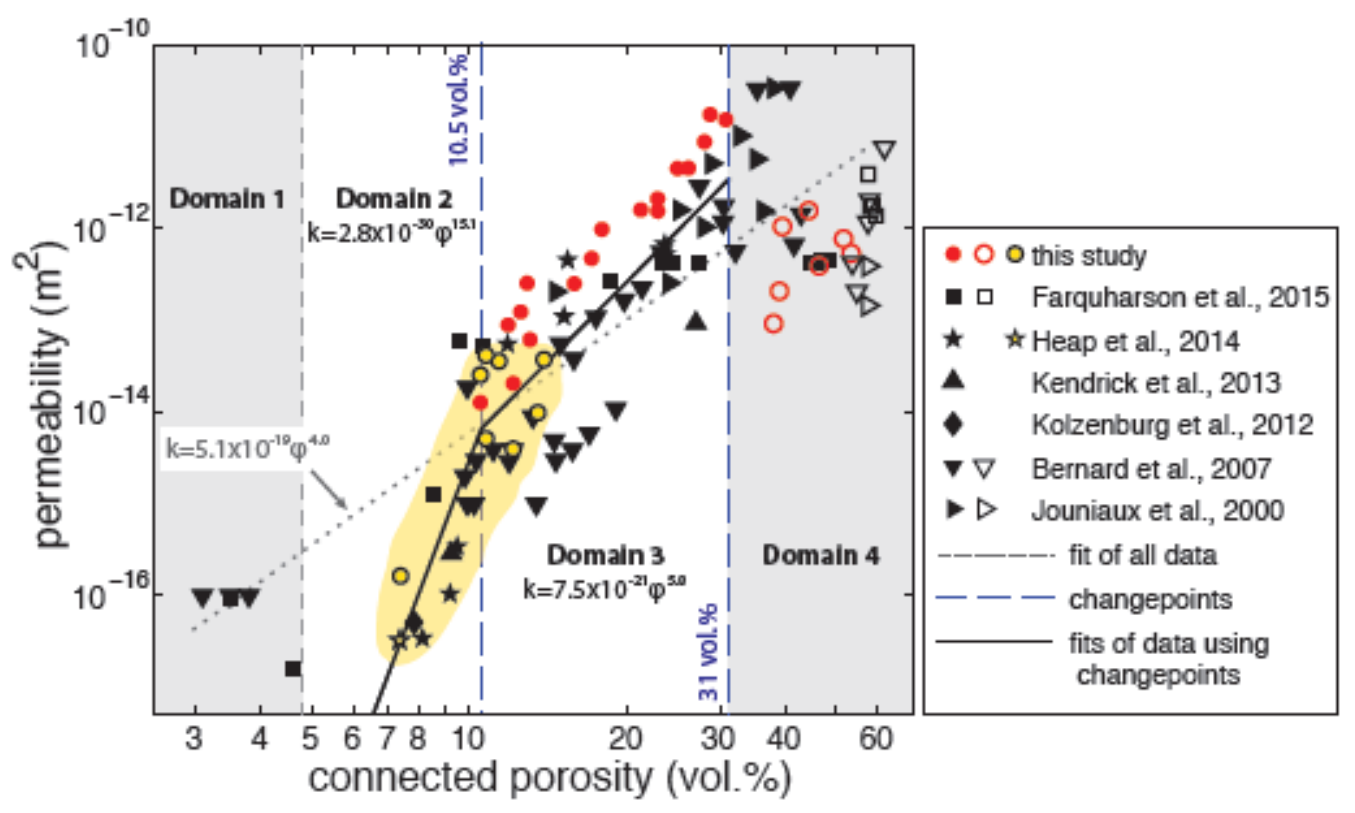

Figure 8 